\title{
The Long Run Performance of Privatization Related ADR Issues
}

\author{
Dr. C. Bülent Aybar \\ Southern New Hampshire University \\ Graduate School of Business \\ 2500 N. River Rd. \\ Manchester, NH 03106
}

Preliminary Draft, February 2001. Please Do not circulate or quote. This paper was presented at AIB 2000 Anmual Meeting in Arizona, Phoenix on November $17-27^{\text {t. }}$.

Correspondence:

Dr. C. Bulent Aybar

Southern New Hampshire University

Graduate School of Business 2500 N. River Rd.

Manchester, NH 03106

Phone: (603) 644-3102 /E-mail: baybar@minerva.nhc.edu 


\section{$\underline{\text { Abstract }}$}

American Depository Receipts (ADRs) have been increasingly used in the Share Issue Privatization process (SIP) by privatizing governments both in developed and developing countries. In this study long-term performance of 143 privatization related ADR programs were analyzed. The ADR programs covered in the study were initiated between 1984 and 1999, and included a diverse mix of companies from 29 different industries across 31 developed an emerging markets. The analysis of the long run performance of these programs revealed interesting patterns. In all cases, average cumulative returns and average cumulative abnormal returns of developed country privatization related ADRs exceeded emerging market privatization returns. Same conclusion was reached by using an alternative return calculation methodology. While sample companies generally outperformed their respective country indices and FT World index, they under performed the S\&P500 Index.

Keywords: Privatization, ADR, Cross-Listing, Equity Issue, International Financial Markets, Emerging Markets

JEL Classification: G15, F30, G32 


\section{1-Introduction}

Privatization is defined as a set of procedures through which government transfers ownership of assets and control of commercial activities to the private sector (Dewenter and Malatesta, 1997). Governments around the world have privatized approximately $\$ 1$ tr worth of assets in the last two decades (Megginson, 2000). A range of methods was used in the privatization process including sales to strategic investors, sale of shares, cash auctions, management and employee buy-outs (MEBO), management contracts and leasing, liquidation, voucher and coupon privatizations. The sale of equity method accounted for a significant portion of the privatization revenues generated by governments since 1980s (Megginson et.al., 1999). An estimated amount of $\$ 700 \mathrm{bn}$ (approximately $70 \%$ of all privatization revenues) was raised through share issue privatizations over the last two decades. This amount signifies the largest surge of equity issuance outside the United States (Megginson, 2000). Popularity of share issue privatization method has increased as governments pressured to privatize large state owned enterprises. The method offered transparency, equity and flexibility in pricing and allocation of ownership. It could also be combined with other methods such as direct sales to strategic investors. However, this method requires reasonably developed equity markets with a sound trading infrastructure and adequate institutional support systems. While the development level of equity markets presented a significant challenge to developing country governments, it was not an irrelevant concern for developed country governments either. 
Despite their relatively developed maket infrastructure, domestic absorption of large multibillion dollar issues was not entirely possible even in countries like Germany, France and Italy. Limitations imposed by the size of individual transactions and the level of stock market development led government issuers to search for alternative venues for the sale of SOE shares. This motivation was compounded by factors such as external account conditions, company characteristics and conditions related to managerial control in postprivatization period. In addition to these, an increasing number of government issuers started to target foreign investors to attract foreign capital flows. In a recent study, Bortoletti et.al (2000), analyzed 392 share issue privatizations between 1977 and 1999. Their findings indicate that $47.2 \%$ of the total public offerings in their sample were international offerings.

This recent surge in privatization pointed out above, overlapped with the globalization of international financial markets. The increasing integration of financial markets created the opportunity for governments to sell equity in foreign markets through cross-listings and private placements. U.S. equity market became a natural center of gravity in this process. The government issuers were attracted to its sophisticated market infrastructure and wide range of institutional choices available to them. An old instrument used in the US market since 1927, American Depository Receipts (ADRs), proved to be particularly attractive for privatization related equity issues. American Depository Receipts have been increasingly used in the Share Issue 
Privatization process (SIP) by privatizing governments both in developed and developing countries.

An interesting and important characteristic of interest has been the short and long run performance of internationally listed shares. In a recent study, Karolyi and Forester (1999) report statistically significant long run underperformance for $\mathrm{ADR}$ issues regardless the origination. However, they indicate that underperformance is far larger for emerging market companies than developed country companies. This finding contradicts with the short run and long run performance studies focusing on Share Issue Privatizations, where significantly positive abnormal returns were reported (Jones et al. (2000) Megginson et.al (1998), Boubakri and Cosset (1999)).

In this study, I intend to contribute to this debate by analyzing the performance of a sample of privatization related ADR issues. The goal of the analysis is straightforward: Documenting the long-run performance of ADR issues by privatized firms. The paper intends to improve on an earlier study by using a significantly larger sample of 143 privatization related ADR issues from 31 countries. Given the increasing importance of privatized firms for individual and institutional investors, I believe it is important to understand how investments in these firms have performed over time. The analysis will also focus on the comparison of developed and developing country privatization related $\mathrm{ADR}$ issue performances as well as the performance in alternative exchange conditions such as issues in New York Stock Exchange versus issues traded Over the Counter. The insights provided by this analysis 
are also likely to be interest to the policy makers, privatization advisors and investment bankers.

\section{2-Privatization, International Share Issues and ADRs}

\section{1-Share Issue Privatizations}

Privatization has dramatically reduced the role of state in economic activity in many reforming countries. Those countries that have adopted largescale privatization programs have been motivated by three principal reasons. First, there is widespread consensus on the evidence that privately-owned firms outperform SOEs in competitive and potentially competitive markets and, second, the empirical evidence clearly shows that privatization significantly enhances the operating and financial performance of divested firms ${ }^{1}$. Third, governments discovered a powerful alternative to raise significant revenues through the sale of SOEs.

While the choice of privatization method is still far from perfectly understood, recent research points to factors such as firm size, fiscal conditions, and the economic development level as the potential determinants $^{2}$. In a survey of empirical studies in privatization, Megginson and Netter (1999) conclude from the extant literature that the larger SOEs and former natural monopolies such as telecommunication companies are more likely to be sold through domestic share offerings in provided that the national stock markets are sufficiently developed. The authors also indicate that

\footnotetext{
${ }^{1}$ For more recent studies see Megginson et.al (1994) and (1998), Boubakri and Cosset (1998) and (1999).

${ }^{2}$ See Megginson and Netter (1998) "From State to Market: Survey of Empirical Articles on Privatization".
} 
government's desire to promote further development of the national stock markets motivate privatizations via share offerings. Privatizing via share offering allows a country without a history of share offerings to establish a reputation for protecting investors through repeated, fair issues. The same strategy also allows a country with an existing poor reputation to change market perceptions.

\section{2-Motivations For International/Global Share Issues in Privatization}

As it was briefly mentioned above, privatization literature indicates that domestic financial market development is often an explicit objective of privatization programs $^{3}$. In this respect, search for alternative venues and decision to list a privatization candidate in international markets may appear to be a paradox, for the fraction of equity to be allocated to foreign investors are traded abroad. While the context of privatization may provide some answers to this puzzle, it is prudent to take a look at the growing literature in crosslistings and global share offerings for answers.

In a recent study investigating the factors determining the global equity offerings by US firms, Wu and Kwok (1999) summarize the motivations for global listings. Several of these motivations may also be shared by privatizing governments. The first relevant motivation suggests that there are windows of opportunity, when otherwise identical firms receive favorable prices for new equity. This timing interpretation implies that managers are able to determine when the market is willing to overpay for their stock and take advantage of these opportunities to issue new equity. 
Consistent with this argument, governments may choose to sell equity abroad to take advantage of hot markets. Another parallel argument suggests that in a segmented international financial market, there may be foreign clientele, who are willing to pay a higher price for the local shares targeted to them. This argument is supported by the view that even in the absence of serious barriers for investment, cross-listings may have several advantages over direct purchasing of shares in foreign markets. These advantages boil down to reduced information acquisition costs and reduced transaction costs.

A stronger and more relevant argument for privatizing governments is that global offerings and cross listings may provide a way of signaling quality. Highly selective investment bank's underwriting and foreign investors' willingness to buy the SOE shares is considered to be certification of quality. Global offerings and cross listings are demanding processes and only a handful of firms can tolerate the energy and cost associated with these transactions $^{4}$. In this sense they are considered to be distinguishing characteristics. Privatizing governments that are trying to establish credibility of their privatization programs may seek certification through international offerings.

Finally, empirical evidence suggests that issuing firms cannot treat the demand for their stocks as if it were perfectly elastic ${ }^{5}$. Rather issuers should recognize that they face a negatively sloped demand curve for their shares.

\footnotetext{
${ }^{3}$ See Bortolotti, Fantini and Scarpa 2000, "Why Governments Sell Privatized Companies Abroad"

${ }^{4}$ See Wu and Kwok (1999 "Why Do US Firms Choose Global Equity Offerings" and Miller (1999) "The Market Reaction to International Cross Listings: Evidence from DRs".

${ }^{5}$ For a comprehensive discussion of this issue see Loderer, Cooney and Van Drunnen (1991) "The Price

Elasticity of Demand for Common Stock" Journal of Finance 46, 621-651.
} 
This leads to a rightward shift in the demand curve such that the total issue can be executed smoothly at higher offer price. This hypothesis does not require foreign investors to overpay for the domestic shares, they just do not underpay for the shares targeted to them. It is obvious that governments with thin equity markets would be concerned about the inelasticity of demand, which could potentially reduce their aggregate privatization revenues.

In another study focusing exclusively on government's motivations to sell equity abroad, Bartolotti et.al (2000) identified six conditions that determine a governments' decision to sell equity abroad. These are public finance conditions, external account conditions, political conditions, institutional conditions- stock market development level, company and transaction characteristic, and conditions related to managerial control in post privatization.

Bartolotti et.al suggest that governments with fiscal problems tend to privatize more, and are motivated to maximize revenues from privatization. Therefore countries with public budget problems should be more likely to use this channel.

The political condition refers to quality signaling. By listing in foreign markets, governments signal the markets that they are committed to privatization, stabilization and structural adjustment policies. Cross listing may also improve the visibility of the government in international markets. External conditions refer to the government's desire to open up export markets 
and attract foreign direct investments. The authors argue that cross listing may improve the firm's ability to penetrate foreign markets. If this argument is true, governments with limited export markets should use this channel to develop export markets for former SOEs. Similarly, cross listing could be used as a strategy to attract foreign capital. Accordingly, countries with limited capital inflows are more likely to resort to sales in foreign markets.

Bartolotti et.al (2000) draw on an earlier work by Perotti (1998), which concludes that right wing governments prefer share issues in the domestic market to strengthen the support for the reform programs. Involving domestic investors in the privatization process through share ownership builds political support to the program. On the other hand, left wing governments are more inclined to maximize revenues. This argument suggests that a left wing government is more likely to use cross listing in the privatization process than a right wing government. Of course this is an empirical issue and needs to be tested.

In reference to institutional conditions Bartolotti et.al argue that institutions define the playground for privatization and may play a role in the decision to cross-list. They refer several factors in this context: Country-risk/Credibility Local Regulations regarding disclosure and minority shareholder protection. This argument suggests that governments with low credibility and lax securities regulations may borrow institutional credibility of another government through cross listing. Therefore higher country risk and 
inadequate local regulations suggest an increase in the likelihood of international offerings and cross listings of privatization issues.

Finally, their explanation regarding the stock market development level suggests that countries with small and less liquid markets are expected to resort to cross-listing more than others. By doing this, governments may want to circumvent the problems associated with market inefficiency such as lack of diversification, information aggregation and monitoring. Some empirical evidence points to efficiency improvements in the domestic market as a result of listing in more efficient markets. It is also difficult to float a large stake in a state owned company in a relatively underdeveloped stock market. Therefore, foreign listings could be the best way to overcome the domestic market limitations

Governments in countries with well-developed markets may not need to bear the cost of global offering. However, to the extent that market segmentation remains as an important barrier, this argument is weakened for the developed markets. Finally, in reference to company's industry characteristics, the company size and the extent of industry openness and the level of global integration/competition in that particular industry are found to be important factors determining the international sale of SOEs.

\section{3-Why Do Governments Use ADRs in International Offerings?}

Forrester and Karolyi (2000) define ADRs as follows:

"American Depository Receipts (ADRs) are negotiable certificates that represent a non-US company's publicly traded equity. They are quoted, trade and pay dividends in U.S. dollars and trade in accordance with U.S. clearing and settlement standards. 
The depositary bank that sponsors the DR program provides all the custodian and safekeeping services for a fee. Each depositary receipt denotes shares that represent a specific number of underlying shares in the home market. The bank can create new receipts for investors when the requisite numbers of shares are deposited in their custodial account in the home market. Cancellations or redemptions of ADRs simply reverse the process and is referred as "flow-back".

Introduction of a new regulatory framework by the U.S. Securities and Exchange Commission (SEC) in 1985 led to emergence of a range of new DR financing tools and energized the otherwise stagnant ADR market. New regulations created a menu of three different ADR programs for foreign companies. "Level I" DRs were introduced as unlisted securities that could trade over-the-counter (as "pink sheet" issues on Nasdaq). Issuing firms could qualify for financial reporting exemptions and did not need to register fully with the SEC; however, this tool did not permit capital raising.

"Level II" DRs and capital-raising "Level III" DRs register and disclose financial statements exactly as domestic U.S. companies and are widely covered by analysts and the press. A new instrument referred as Rule 144A was adopted in April 1990. Forrester and Karolyi (2000) suggest that this program was designed to serve a number of purposes including increasing the overall liquidity of private placement securities. Private placements are only available to qualified institutional buyers (QIBs), with at least $\$ 100$ million in securities and registered broker-dealer accounts. These securities trade overthe-counter among QIBs using the PORTAL system. Another purpose of Rule 144A was to provide increased access to U.S. capital markets specifically to non-U.S. issuers, by not requiring them to undergo registration under the 
Securities Act. Rule 144A allows non-U.S. issuers to include U.S. tranches in global equity offerings without having to comply with certain disclosure rules.

Availability of these instruments created a very effective access route to the wealthiest capital market with a large investor pool. Although ADRs offer a cheaper access to US market, Miller (1999) indicates that initial fees alone can exceed \$1 million for major exchange DRs (Level-II and Level-III), because they are required to reconcile to U.S. GAAP, report financial statements quarterly and meet the listing requirements of the particular US exchanges that they trade. On the other hand, companies establishing Level-I programs can be exempted from compliance to US GAAP and SEC disclosure requirements by filing 12g3-2b exe mption from the 1934 Exchange Act (Miller 1999).

In summary, ADRs provide a step-by-step introduction to a large individual and institutional investor pool in U.S. for foreign companies. Initial tranches of privatization may achieve the desired visibility and credibility expected from an international offering through less demanding and less expensive 144A or Level-I ADR programs. As the experience culminates, government organizations in charge of privatization may switch to more sophisticated programs. This step-by-step approach is also consistent with the revenue maximizing strategies adopted by governments utilizing share issue privatizations.

\subsection{Evidence on Long Term Performance}

Long term returns on seasoned and unseasoned share issues was not studied until the Jay Ritter's (1991) seminal paper on long term performance of IPOs 
in US. The publication of this paper triggered a wealth of studies focusing on long-term performance of stock issues. However, studies analyzing long-term performance of privatization related share issues are scarce. A group of studies document significant positive long run abnormal returns in UK share issue privatizations (Lewis, 1993; Inganyete ,1995; Menyah and Paudyal, 1996). The evidence on continental European privatizations are mixed. While Davidson and Rosgen (1996) and Davidson, Rosgen, and Simon(1997) report negative returns on French and Italian privatization issues between 1990-1996, their study reveals positive returns for a European sample. Studies covering a diverse sample of share issue privatizations report significantly positive returns (Boardman and Laurin, 1996; Dewenter and Malatesta,1997). In a more recent study Megginson, Nash, Netter and Schwarz (1998) analyzed buy and hold returns in a comprehensive sample of 264 share issue privatizations from 36 countries. Megginson et.al. report $19 \%, 54 \%$ and $107.9 \%$ positive abnormal returns for 1,3 and 5 year holding periods respectively. Boubakri and Cosset (1999) report similar results for a sample of 120 developing country share issue privatizations. They indicate that average unadjusted buy and hold returns for Developing Country privatization issues are about 112.4\%. Abnormal returns calibrated for market index and matching size and book to market control portfolio are more moderate, $46.5 \%$ and $36.5 \%$ respectively.

Finally, Forrester and Karolyi (2000) analyze long-term performance of 333 global equity offerings from 35 countries. Their results indicate that these 
issues under perform local and global benchmarks by $8 \%$ and $39 \%$ over the three years following the issuance. They report $34.79 \%$ negative abnormal returns for a sample of 68 privatizations. This result contradicted the earlier evidence of significant positive performance over the benchmarks presented in the literature and motivated this study which looks at the long term performance of 143 privatization related ADR issues.

\section{$\underline{\text { 3-Data and Methodology }}$}

\subsection{Data}

The data on ADR issues comes from a database provided by the Bank of New York ADR Division. This data set includes names, CUSIP, trading symbol, nationality, type of ADR, and the exchange and effective dates of issue. This data was matched with privatization deals listed in Privatization International Yearbooks, and other issues reported in various published work on Share Issue Privatizations, notably an appendix provided by William Megginson ${ }^{6}$ on his web page.

The individual company price data and benchmark data was retrieved from DataStream International. The overlap between Bank of NY ADR data and privatization share issues created a sample of 240 companies. Price data availability and the trading period reduced the sample size to 143 companies from 31 countries. The sample is composed of 107 emerging market and 36 developed market companies. Companies came from a diverse set of industries ${ }^{7}$.

\footnotetext{
${ }^{6} \mathrm{http} / /$ www.uo.edu/faculty/megginson/index.html
}

${ }^{7}$ See table-3 


\subsection{Methodology}

Long run return estimation methodology in this study follows the Ritter (1991), Affleck-Graves (1995) and Forrester-Karolyi (2000). Monthly holding period returns for each firm are calculated as geometric returns over consecutive monthly periods subsequent to the issuance day. The monthly intervals are computed from the issuance in fixed length intervals regardless of calendar month-end dates where $\mathrm{R}_{\mathrm{i}, \mathrm{d}}$ is the return (price change) on stock $\mathrm{i}$

$$
R_{i, m}=\prod_{d=1}^{21}\left(1+R_{1, d}\right)-1, i=1, \ldots \ldots \ldots N
$$

during month $\mathrm{m}$, and $\mathrm{N}$ is the number of firms with an ordinary ADR exchange listing or private placement - for the overall sample in this study $\mathrm{N}$ is 144. Monthly retums are calculated for $12,24,36$ and 60 months subsequent to the ADR issuance or private placement. As in the other studies measuring long run performance day 0 is excluded (2) nthly return calculations since many investors are not able to purchase the ADR at the issue price. Average return for each month $\mathrm{m}$ is calculated across firms by using:

$$
R_{m}=\left(1 / N_{m}\right) \sum_{1}^{N} R_{i, m}, m=1, \ldots \ldots . .60
$$

Cumulative returns are calculated with the implicit assumption of monthly rebalancing, which assumes that when data for a firm in a particular month's portfolio is not available, the portfolio return for the next month is an equal 
weighted average of the remaining firms in the portfolio. Monthly returns are cumulated geometrically over the entire period of interest.

$$
C R_{t 1, t 2}=\prod_{m=f 1}^{22}\left[1+R_{m}\right]-1
$$

Subscripts $t_{1}$ and $t_{2}$ denote the beginning and ending periods respectively. All returns are calculated in US\$.

Two methods were used to evaluate the long run performance. First method uses cumulative abnormal returns (CAR) calculated in the traditional event study manner with the monthly portfolio rebalancing where the adjusted returns are computed using several different benchmarks. In general abnormal returns denoted $A R$ are calculated as

$$
A R_{i, m}=R_{i, m}-R_{m}^{I}, i=1, \ldots \ldots, n
$$

Where $\mathrm{R}_{\mathrm{m}}^{\mathrm{I}}$ is a market index return during month $\mathrm{m}$. For each month, average abnormal return across firms are calculated as

$$
A R_{m}=(1 / N) \sum_{i=1}^{N m} A R_{i, m}, m=1,2, \ldots \ldots, 60
$$

Following the Forrester-Karolyi (1999) several benchmark tests are used to reflect the perspectives of different group of investors. Local market index returns denominated in U.S. dollars are used to represent the perspective of the local market investors. S\&P500 index is used to calibrate the ADR returns for the US investors. Finally FT-World Index is used to reflect the perspective of the global investors.

Cumulative abnormal returns (CAR) are calculated as follows:

$$
C A R_{t, t 2}=\prod_{m=t 1}^{\prime 2}\left(1+A R_{m}\right)-1
$$


In long run CAR calculations Forrester and Karolyi suggest assigning 0 for the ADR issues with missing data. In other words, I assume that their return is equal to the benchmark return.

The second method uses a "buy and hold" returns for the ADR issues and the benchmarks. Individual ADR abnormal holding period returns calibrated for the selected index are calculated as follows:

$$
A H P R_{i, t 1, t 2}=\prod_{m=t 1}^{t 2}\left[1+R_{i, m}\right]-\prod_{m=t 1}^{t 2}\left[1+R_{m^{m}}^{I}\right]
$$

\section{Significance Tests:}

The significance of the raw and abnormal returns is tested by using t-Statistics. These statistics became the standard in long-term performance literature since Ritter (1991). T-statistic for the raw and abnormal returns are computed as $R t$ $. n_{t} / s d_{t}$ where $\mathrm{R}_{\mathrm{t}}$ is the average raw return for month $\mathrm{t}\left(\mathrm{AR}_{\mathrm{t}}\right.$ for abnormal return), $\mathrm{n}_{\mathrm{t}}$ is the number of observations in month $\mathrm{t}$, and $s d_{t}$ is the crosssectional standard deviation of returns for month $t$. T-statistics for the cumulative average return $\mathrm{CR}_{\mathfrak{f}}$ (or Cumulative Average Abnormal Return CAR) in month $\mathrm{t}$, is computed as $C R_{t} . n_{t} / \operatorname{cs} d t$ where $c s d t$ is computed as $c s d t$ $=[t \cdot \operatorname{var}+2 \cdot(t-1) \cdot \operatorname{cov}]^{1 / 2}$, where var is the average cross-sectional variance, and $\operatorname{cov}$ is the first-order autocovariance of the $\mathrm{R}_{\mathrm{f}}$ series in particular month.

\section{4-Results}

The overall average monthly returns assuming monthly portfolio rebalancing subsequent to the issue of ADRs are reported in table-4a. These unadjusted returns are in U.S. dollars. A brief review of the overall sample averages 
indicates that 30 of the 36 average monthly returns are positive. Average monthly returns range between $+3.69 \%$ and $-2.78 \%$. However, variation across the companies for a given month is significant. A simple test of significance indicates that only 3 of these average monthly returns are significantly different than zero. On the other hand, cumulative returns based on monthly rebalancing are high. They reach to $18.8 \%, 36.5 \%$, and $45.2 \%$ at the end of $12^{\text {th }}, 24$ th, and $36^{\text {th }}$ month respectively, and all are statistically significant.

A review of emerging market and developed market sub-samples reveal interesting results (see table-4b). While emerging market average monthly returns range between $+4.6 \%$ and $-3.4 \%$, developed country average monthly returns fall into the range of $+6.45 \%$ and $-1.64 \%$ (see table- $4 \mathrm{c}$ ). Developed country monthly returns are significantly larger than developing country monthly returns based on month-by-month assessment of the average returns.

Differences in cumulative returns are more resounding. At the end of the $36^{\text {th }}$ month, monthly returns on developed country issues cumulate to $70.63 \%$, while emerging market issues reach to $37.43 \%$.

The analysis of ADR issue performances with respect to three alternative benchmarks, local market index, S\&P500 and Financial Times World Index will be discussed next. There are two reasons why I employ three different benchmarks in this part. First, there is a widely shared concern about the biases imposed by the selection of a particular benchmark. In order to alleviate this concern I intend to check the robustness of abnormal returns across the 
benchmarks. Second, each index reflects the perspective of a particular investor group. For instance, the use of S\&P500 is justified because performance with respect to this index is of interest to US investors considering investments in ADR issues. Similarly use of FT World reflects the perspective of a globally diversified investor.

The first benchmark is the dollar returns on the local market portfolio. I used Morgan Stanley Capital International (MSCI) Country Index for each issue as a proxy for the local market returns. Average abnormal monthly returns range between $+2.9 \%$ and $-1.9 \%$, and 12 of the 36 average monthly abnormal returns are negative. Cumulative abnormal returns are $9.6 \%, 15.3 \%$ and $16.6 \%$ at the end of the $12^{\text {th }}, 24^{\text {th }}$, and $36^{\text {th }}$ month respectively. All of the cumulative abnormal returns are significantly positive with the exception of $7^{\text {th }}$, 8th and $9^{\text {th }}$ months (see table-5a).

While the overall sample points to over performance with respect to local market, analysis of sub-samples warrants some caution with this conclusion. The corresponding cumulative abnormal returns for emerging market issues at the end of $12^{\text {th }}, 24^{\text {th }}$ and $36^{\text {th }}$ months are $6.7 \%, 12.9 \%$ and $15 \%$ respectively. Cumulative abnormal returns are not significantly different than zero with the exception of 2 nd, $3^{\text {rd }}, 4^{\text {th }}, 18^{\text {th }}$ and $29^{\text {th }}$ months.

On the other hand, developed market issues yield $18.45 \%, 22.25 \%$ and $21.48 \%$ for 12,24 and 36 month periods. All the cumulative returns are significantly different than zero for this sub-sample. 
These results indicate that while developed market issues outperform their respective local market indices, this cannot be concluded for the emerging market issues due to significant variation across the company performances in this sub-group. In other words abnormal cumulative returns are not consistently significantly larger than zero.

On a month-by-month basis, developed country average abnormal returns adjusted for the local market indices are significantly larger than emerging market average abnormal returns adjusted for their local indices.

Analysis of overall sample returns adjusted for S\&P500 as an alternative benchmark reveals that $\mathrm{ADR}$ issues on average under perform this index by $15.13 \%$ by the end of the $36^{\text {th }}$ month. This result is consistent with the results reported in Forrester and Karolyi (1999). Analysis of sub-samples confirms the earlier indications that developed country issues perform better than emerging market issues. While the 36 month emerging market cumulative abnormal returns are $-19.02 \%$, underperformance for developed country issues are mere $-2.78 \%$.

A review of monthly average abnormal returns and cumulative abnormal returns with respect to FT World index suggests that long run performance is sensitive to the choice of benchmark. Overall returns calibrated for FT World index indicate $+6.16 \%,+7.18 \%$ and $+12.12 \%$ cumulative abnormal returns for 12,24 and 36 months respectively 
(see table-7a). While the cumulative abnormal returns for emerging market issues narrows down to $+2.52 \%$ (see table-7b) at the end of the $36^{\text {th }}$ month, developed country issue returns cumulate to $+38.41 \%$ (see table- $7 \mathrm{c}$ ).

In addition to comparative analysis of long term performance of developed and emerging market issues, a possible linkage between the type and the setting that the ADRs are traded, and the long term performance was investigated. Our sample includes Level-I, Level-II, Level-III and 144A ADR issues. The difference between these programs was described in section 2 of the paper. Level-I issues are traded in the over the counter ("OTC") market and it is the fastest growing segment of the market. The vast majority of the 1,225 sponsored ADR programs are Level-I facilities. Level-II and Level-III programs are traded on NYSE, AMEX or NASDAQ. In our sample 57 of the 67 Level-II and Level-III programs are traded in NYSE. These are the most expensive and demanding programs regarding compliance and disclosure requirements. As it was mentioned earlier, Level-III programs are used to raise capital. Finally $144 \mathrm{~A}$ Depository Receipts are capital raising issues in which securities are privately placed to qualified buyers.

A review of abnormal cumulative returns (raw returns adjusted for country index) suggests that $144 \mathrm{~A}$ issues under-perform the country index by $14.05 \%$ at the end of the third year. On the other hand NYSE issues (Level-II and Level-III programs) and OTC issues (Level-I programs) outperform the country index by $25.84 \%$ and $51.12 \%$ respectively. While $144 \mathrm{~A}$ and NYSE traded Level-II-Level-III programs under-perform the S\&P500 index, OTC 
traded Level-I issues outperform the S\&P500 by $7.43 \%$ at the end of 3 years (see table-8b). OTC and NYSE issues outperform the FTWorld index by $60.11 \%$ and $21.69 \%$ respectively. $144 \mathrm{~A}$ issues continue to under perform, when they are tested against FTWorld index, this time by $23.17 \%$.

These results indicate that OTC traded Level-I issues perform better than Level-II, Level-III and 144A issues. Underperformance of $144 \mathrm{~A}$ issues is notable. Controlling the development level of the economy that each issue originates (Developed/Emerging dichotomy in this case) does not change the results qualitatively.

Finally, I measured the long-term performance by using an alternative method. In this method 12, 24 and 36 month buy and hold returns were calculated (see table-9). These results are consistent with the previous results based on the monthly portfolio balancing return methodology.

In the overall sample, 36-month holding period returns are $20.35 \%$. Interestingly, holding period returns increase from $21.35 \%$ at the end of the $12^{\text {th }}$ month to $30.83 \%$ at the end of $24^{\text {th }}$ month, then decline to $20.35 \%$. As in the previous analysis, 36-month buy and hold (B-H) returns are significantly lower for emerging markets group than developed group.

Abnormal holding periods based on alternative benchmarks are also consistent with the previously reported results. As the 36-month holding period abnormal returns for the entire sample are significantly negative for FT World and S\&P500 benchmarks, they are positive for the country index. The 36month holding period returns- for emerging markets group is positive for 
country index, but it is negative for FTWorld and S\&P500. Abnormal holding period returns for S\&P500 benchmark reveals a dramatic underperformance at $-74.65 \%$ (see table-9). Developed country group 36-month abnormal holding period returns are positive with the exception of S\&P500 benchmark. The performances of these two groups differ significantly for 24 and 36 month holding periods. The differences for 12 month holding periods are not statistically significant (see table-9)

\section{$\underline{\text { 5-Concluding Remarks }}$}

In this study, a sample of 143 privatization related ADRs' long-term

performance was analyzed. The ADR programs covered in the sample were initiated between 1984 and 1999; however, only five of the 143 programs analyzed became effective before 1991. The sample included a diverse mix of companies from 29 different industries across 31 countries.

The analysis of the long run performance of these programs revealed interesting patterns. In all cases, average cumulative returns and average cumulative abnormal returns (returns adjusted for selected benchmarks) of developed country privatizations exceeded emerging market privatization returns. Same conclusion was reached by using an alternative return calculation methodology -buy and-hold returns. While sample companies generally outperformed their respective country indices and FT World index, they under performed the S\&P500. This can be attributed to the superb performance of the US equity market during 1990s, which overlapped with the performance measurements of the $96.5 \%$ of the sample companies. 
Poor performance of emerging market issues is paradoxical. In theory, listing in a more advanced equity market should be beneficial for emerging market companies and the decline in cost of capital should be more dramatic as compared to developed country market companies. Of course this issue warrants further investigation since the methodology employed here is not based on an asset-pricing model, and risk-return characteristics of the companies were not given consideration in the study. The analysis conducted in this study also ignores the returns on initial offerings. It is plausible that some companies capture the benefits by the end of the first day closing, and the returns calculations from the first day closing price may exclude this component. Another possible explanation for the underperformance may be associated with the status of the privatized companies. The companies in the sample are at different stages of privatization process, and in some cases residual government share is still significant. It is likely that lingering government involvement and, failure in the smooth execution of privatization may increase risks and undermine the company performance in the post issue period. This is more likely to happen in emerging market settings than the developed country settings. This issue will be addressed in a follow up work. The analysis of different type of ADR programs used by the privatizing governments revealed a rather surprising pattern. Level-I issues traded in the OTC market performed significantly better than Level-II and Level-III programs as well as $144 \mathrm{~A}$ private placements. International public offering 
and cross-listing literature suggests that signals sent by Level-II and Level-III programs should lead to a sharper decline in the cost of capital of the issuers due to an expected increase in transparency and more effective shareholder monitoring as compared to Level-I programs. These performance differences can be attributed to size and risk characteristics of the sample companies, which were not considered in this analysis.

The sample size and simplicity of the methodology employed in this analysis does not allow us to make far-reaching generalizations of the study results. However, these results motivate further investigation of the identified patterns by using alternative methodologies and considering a wider range of variables that would help to describe the context of the privatization for each company. 


\section{REFERENCES}

Baldwin, Carliss Y. and Sugato Bhattacharyya, 1991, Choosing The Method Of Sale: A Clinical Study Of Conrail, Journal of Financial Economics 30, 6998 .

Beatty, Randolph P. and Ivo Welch, 1996, Issuer Expenses And Legal Liability In Initial Public Offerings, Journal of Law and Economics 39, 545 602 .

Benveniste, M. Lawrence and Walid Y. Busaba 1998, Book Building Versus Fixed Price: An Analysis Of Competing Strategies For Marketing IPOs, Journal of Financial and Quantitative Analysis 32, 383-404.

Black, Bernard S. and Ronald J. Gilson, 1998, Venture Capital And The Structure Of Capital Markets Versus Stock Markets, Journal of Financial Economics 47, 243-277.

Boardman, Anthony and Aidan R. Vining, 1989, Ownership And Performance In Competitive Environments: A

Comparison Of The Performance Of Private. Mixed. And State-Owned Enterprises, Journal of Law and Economics

32, 1-33.

Boardman, Anthony E. And Claude Laurin, 1998, The Performance Of Privatised British Public Utilities And The Windfall Profits Tax Working Paper-University of British Columbia.

Bortolotti B, Fantini M, Scarpa C, 2000, Why do Governments Sell Privatized Companies Abroad; Working Paper, Fondazione Eni Enrico Mattei, Milan, Italy.

Boubakri N.and J.C. Cosset, The After Market Performance of Privatization Offerings in Developing Countries, Paper Presented in 1999 AIB Annual Conference.

Boubakhri, Narjess and Jean-Claude Cosset, 1998, The Financial And Operating Performance Of Newly Privatized Firms: Evidence From Developing Countries, Journal of Finance.

Dewenter, Kathryn and Paul H. Malatesta, 1997, Public Offerings Of StateOwned And Privately -Owned Enterprises: An International Comparison, Journal of Finance 52, 1659-1679. 
D'Souza, Juliet, and William L. Megginson, 1999. The Financial And Operating Performance Of Newly Privatized Firms In The 1990s, Journal of Finance; 54

Foerster S. and Karolyi A, The Long Run Performance of Global Equity Offerings, Journal of Financial and Quantitative Analysis, Vol. 35 No: 4 December 2000.

Jones, W. Megginson, R. Nash, J. Netter, Share Issue Privatizations and Financial Means to Political and Economic Ends, Journal of Financial Economics 2000

Keloharju, Matti, 1994, Initial IPO Returns And The Characteristics Of PostIPO Financing In Finland, Working Paper Helsiniki School of Economics and Business Administration.

Loughran, Tim, Jay R. Ritter, and Kristian Rydqvist, 1994, Initial-Public Offerings: International Insight, Pacific-Basin Finance Journal 2, 165-199.

Megginson, William L., Robert C. Nash, Jeffry M. Netter, and Adam L. Schwartz, 1998, The Long Term Return To Investors In Share Issue Privatizations, Working paper, University of Georgia, Athens, GA.

Megginson, William L., Robert C. Nash, Jeffry M. Netter, and Annette B. Poulsen, 1997, The Choice Of Privatization Method: An Empirical Analysis, Working Paper, University of Georgia, Athens, GA.

Megginson, William L., Robert C. Nash, and Matthias VanRandenborgh, 1994, The Financial And Operating Performance Of Newly Privatized Firms: An International Empirical Analysis. Journal of Finance, 49, 403-452.

Megginson, William and Jeffry Netter, 1998, From State to Market: A Survey of Empirical Articles on Privatization, New York Stock Exchange Working Paper.

Menyah, Kojo and Krishna Paudyal, 1996, Share Issue Privatisations: The UK Experience, In Mario Levis (Ed.). Empirical Issues In Raising Equity Capital, Elsevier Science, Amsterdam.

Menyah, Kojo, Krishna Paudyal, and Charles G. Inyangete, 1995, Subscriber Return, Underpricing, And Long-Term Performance Of U.K. Privatization Initial Public Offers, Journal of Economics and Business 47 , $473-495$. 
Mikkelson, Wayne H., and M. Megan Partch, 1986, Valuation Effects Of Security Offerings And The Issuance Process, Journal of Financial

Economics 15, 31-60.

Miller Darius, 1999, "The Market Reaction to International Cross Listings: Evidence from Depositorv Receipts", Journal of Financial Economics 51 $103-123$.

Muscarella, Chris J. And Michael R. Vetsuypens, 1989. A Simple Test Of Baron's Model Of IPO Underpricing, Journal of Financial Economics 24, 125-135.

Perotti, Enrico and Serhat E. Guney, 1993, Successful Privatization Plans: Enhanced Credibility Through Timing And Pricing Of Sales, Financial Management 22, 84-98.

Perotti, Enrico, 1995, Credible Privatization, American Economic Review 85, 847-859.

Speiss, D., and J. Affleck-Graves, 1995, Under-Performance In Long-Run Stock Returns Following Seasoned Equity Offerings, Journal of Financial Economics 38, 243-267.

Wu and Kwok Chuck, 1999, "Why US Firms Choose Global Equity Offerings", Paper presented at 1999 AIB Annual Meeting, Charleston, South Caroline. 
Table-1: Sample Characteristics-Number of companies from each country

\begin{tabular}{lc}
\hline Country & $\begin{array}{c}\text { Number of } \\
\text { Companies }\end{array}$ \\
\hline Argentina & 5 \\
Austria & 3 \\
Australia & 2 \\
Brazil & 17 \\
Chile & 2 \\
China & 24 \\
France & 8 \\
Greece & 3 \\
Hungary & 7 \\
Indonesia & 4 \\
India & 3 \\
Ireland & 2 \\
Israel & 2 \\
Italy & 3 \\
Japan & 4 \\
Korea & 7 \\
Malaysia & 2 \\
Mexico & 2 \\
Netherlands & 3 \\
Norway & 1 \\
Peru & 3 \\
Philippines & 2 \\
Poland & 6 \\
Portugal & 4 \\
Russia & 5 \\
Singapore & 2 \\
Spain & 2 \\
Taiwan & 2 \\
Thailand & 2 \\
UK & 2 \\
Venezuela & 2 \\
Total & 2 \\
\hline & 2 \\
\hline
\end{tabular}


Table-2: Allocation of Issues by the exchange for each country

\begin{tabular}{|c|c|c|c|c|c|c|}
\hline Country & $144 \mathrm{~A}$ & NYSE & OTC & Other & \multicolumn{2}{|c|}{ Grand Total } \\
\hline Argentina & 2 & & 3 & & & 6 \\
\hline Austria & 2 & & & 1 & & 3 \\
\hline Australia & 1 & & 1 & & & 2 \\
\hline Brazil & 1 & 1 & 1 & 4 & 1 & 17 \\
\hline Chile & & & 2 & & & 2 \\
\hline China & 4 & & 9 & 9 & 3 & 24 \\
\hline France & 3 & & 4 & & 1 & 9 \\
\hline Germany & & & 1 & & & \\
\hline Greece & 1 & & 2 & & & 3 \\
\hline Hungary & 2 & & 1 & 1 & 3 & 7 \\
\hline Indonesia & 4 & & & & & 4 \\
\hline India & 1 & & 2 & & & 3 \\
\hline Ireland & & & 1 & 1 & & 2 \\
\hline Israel & 1 & & 1 & & & 2 \\
\hline Italy & 1 & & 2 & & & 3 \\
\hline Japan & 1 & & 1 & 2 & & 4 \\
\hline Korea & 4 & & 3 & & & 7 \\
\hline Malaysia & & & & 2 & & 2 \\
\hline Mexico & & & 1 & & 1 & 2 \\
\hline Netherlands & & & 2 & 1 & & 3 \\
\hline Norway & 1 & & & & & 1 \\
\hline Peru & & & 2 & 1 & & 5 \\
\hline Philippines & 1 & & & 1 & & 2 \\
\hline Poland & 6 & & & & & 6 \\
\hline Portugal & 1 & & 2 & & 1 & 4 \\
\hline Russia & 2 & & & 7 & & 9 \\
\hline Singapore & & & & 2 & & 2 \\
\hline Spain & & & 2 & & & 2 \\
\hline Taiwan & 2 & & & & & 2 \\
\hline Thailand & 1 & & & 1 & & 2 \\
\hline UK & 1 & & 3 & 1 & & 5 \\
\hline Venezuela & & & 1 & & & 1 \\
\hline Total & 43 & 5 & 7 & 34 & 9 & 143 \\
\hline
\end{tabular}


Table-3: Sample Characteristics-Number of companies in each industry

\begin{tabular}{lr}
\hline Industry & Companies \\
\hline Airline/Airline Services & 2 \\
Automobile & 5 \\
Beverages & 1 \\
Financial Services/Banking & 12 \\
Chemicals/Petrochemicals & 8 \\
Consumer Electronics & 1 \\
Coal & 1 \\
Construction/Building Materials & 4 \\
Pharmaceuticals & 1 \\
Electrical Equipment & 5 \\
Extraction and Exploration & 2 \\
Engineering & 1 \\
Food & 2 \\
Insurance & 1 \\
Investment & 1 \\
Machinery & 1 \\
Mining & 5 \\
Multi-Industry/Conglomerate & 3 \\
Oil and Gas Exploration Dev. Servs. & 15 \\
Other & 2 \\
Paper & 1 \\
Plastic & 1 \\
Resources & 1 \\
Rubber & 33 \\
Shipyard & 3 \\
Steel & 2 \\
Services & 1 \\
Telecom & 1 \\
Transportation & 7 \\
Utilities & 1 \\
Total & 1 \\
\hline &
\end{tabular}


Table-4a: Average Monthly Returns in the sample

The average retums inchudeall compamies in the sample. T-statistic for the raw and abnommal returns are computedas $R t . n_{t} / s d_{t}$ whereRt is theaverage raw retum for montht (AR for abnomal retum), $n$ is thenumber of observations in montht, and $s d_{i}$ is the cross-sectional standard deviation of retums for montht T-statistics for the cumulative average retum (orCumulative Average Abnomal RetumCAR) inmonth $\mathrm{CR}_{\mathrm{e}}$ iscomputed as $\mathrm{R}_{t}$. nt $/$ csdt where csdt is computed as csat $=[t . \mathrm{var}+2 .(t-1)$. $\operatorname{cov}^{7 / 2}$, wherevar is the average cross-sectional variance, and $c o v$ is the first-order autocovariance of the Rseries in particular month.

\begin{tabular}{rrrrrr}
\hline Month & \multicolumn{1}{l}{ Firms } & \multicolumn{2}{c}{ R } & \multicolumn{1}{l}{-value } & \multicolumn{2}{l}{ l-value } \\
\hline 1 & 143 & 0.015945 & 1.052715 & 0.015945 & 1.210167 \\
2 & 143 & 0.031169 & 1.809512 & 0.047612 & 2.554882 \\
3 & 143 & 0.020779 & 1.454831 & 0.06938 & 3.039713 \\
4 & 143 & 0.029105 & 2.510329 & 0.100504 & 3.813347 \\
5 & 143 & 0.005945 & 0.507166 & 0.107047 & 3.632755 \\
6 & 143 & 0.032383 & 2.734016 & 0.142896 & 4.426791 \\
7 & 143 & 0.003938 & 0.326447 & 0.147396 & 4.227469 \\
8 & 143 & 0.014487 & 1.0372 & 0.164019 & 4.400371 \\
9 & 143 & 0.004518 & 0.363913 & 0.169278 & 4.281728 \\
10 & 143 & -0.01714 & -1.34764 & 0.149231 & 3.58094 \\
11 & 143 & 0.014121 & 0.824134 & 0.165458 & 3.785565 \\
12 & 143 & 0.01992 & 1.502487 & 0.188674 & 4.13294 \\
13 & 142 & 0.020254 & 1.605739 & 0.212749 & 4.461794 \\
14 & 142 & 0.010671 & 0.849683 & 0.22569 & 4.561009 \\
15 & 137 & 0.036904 & 2.219325 & 0.270923 & 5.195522 \\
16 & 135 & 0.00892 & 0.710321 & 0.282259 & 5.202632 \\
17 & 133 & 0.009782 & 0.73347 & 0.294802 & 5.232387 \\
18 & 132 & 0.016025 & 1.067612 & 0.315552 & 5.42236 \\
19 & 132 & 0.007913 & 0.691116 & 0.325961 & 5.451838 \\
20 & 130 & 0.000948 & 0.069261 & 0.327218 & 5.293714 \\
21 & 128 & -0.00064 & -0.05232 & 0.326369 & 5.112937 \\
22 & 128 & 0.014584 & 0.868805 & 0.345713 & 5.291456 \\
23 & 128 & 0.014886 & 1.068544 & 0.365745 & 5.475014 \\
24 & 127 & 0.00048 & 0.02786 & 0.3664 & 5.348331 \\
25 & 119 & 0.015419 & 1.11632 & 0.387469 & 5.364212 \\
26 & 114 & 0.028916 & 2.072125 & 0.427588 & 5.681425 \\
27 & 114 & 0.011837 & 1.009855 & 0.444487 & 5.795553 \\
28 & 113 & 0.001091 & 0.086628 & 0.446063 & 5.686199 \\
29 & 111 & 0.011325 & 0.822971 & 0.46244 & 5.740942 \\
30 & 108 & 0.0181 & 1.195798 & 0.48891 & 5.886342 \\
31 & 107 & -0.01666 & -1.10115 & 0.46411 & 5.471385 \\
32 & 106 & 0.003178 & 0.297632 & 0.468764 & 5.413735 \\
33 & 103 & 0.032499 & 2.016707 & 0.516497 & 5.790212 \\
34 & 102 & -0.00296 & -0.24128 & 0.512005 & 5.627295 \\
35 & 102 & -0.0121 & -0.70078 & 0.493708 & 5.348123 \\
36 & 101 & -0.02783 & -2.02787 & 0.452136 & 4.80555 \\
\hline & & & & & \\
& & & &
\end{tabular}


Table-4b: Average Monthly Returns-Emerging Market Companies The aveage monthly retums $R$ and Cumulative Retums(CR) were calculated for only energing market countries. T-stetistic for theraw and abnomal retums are computed as $R t . n_{t} / s d_{t}$ where Rt is the average raw retum for montht (AR for abnomal retum), $n$ is thenumber of observations in montht, and $s d_{t}$ is the cross-sectional standard deviation of returns for month t. T-statistics for the cumulative average retum (or Cumulative Average Abnomal RetumCAR)inmontht, $\mathrm{CR}_{\mathrm{t}}$ iscomputed as $\mathrm{CR}_{t}, n t / \mathrm{csdt}$ where csdt is computedas csdt $=[t . v a r+2 \cdot(t-1) . \operatorname{cov}]^{1 / 2}$, wherevar is the average cross-sectional variance, and $c o v$ is the first-onder autocovariance of the Reries in particularmonth.

\begin{tabular}{rrrrrr}
\hline Month & \multicolumn{1}{l}{ Firms } & \multicolumn{2}{c}{ R } & \multicolumn{1}{c}{ t-Value } & \multicolumn{2}{c}{ t-value } \\
\hline 1 & 107 & 0.006011 & 0.322122 & 0.006011 & 0.35484 \\
2 & 107 & 0.03748 & 1.647848 & 0.043716 & 1.825071 \\
3 & 107 & 0.006078 & 0.377127 & 0.050059 & 1.706485 \\
4 & 107 & 0.028108 & 1.908913 & 0.079574 & 2.349254 \\
5 & 107 & 0.00306 & 0.199824 & 0.082878 & 2.188502 \\
6 & 107 & 0.031117 & 2.058941 & 0.116574 & 2.810112 \\
7 & 107 & -0.00199 & -0.12878 & 0.11435 & 2.552048 \\
8 & 107 & 0.011639 & 0.662491 & 0.127321 & 2.658006 \\
9 & 107 & 0.003019 & 0.188428 & 0.130724 & 2.572993 \\
10 & 107 & -0.02127 & -1.31893 & 0.10667 & 1.991806 \\
11 & 107 & 0.014854 & 0.655627 & 0.123108 & 2.191781 \\
12 & 107 & 0.021374 & 1.268103 & 0.147114 & 2.507673 \\
13 & 106 & 0.021706 & 1.31306 & 0.172014 & 2.803889 \\
14 & 106 & 0.013975 & 0.850945 & 0.188393 & 2.95917 \\
15 & 103 & 0.033269 & 1.548629 & 0.22793 & 3.409502 \\
16 & 101 & 0.000184 & 0.011441 & 0.228155 & 3.272264 \\
17 & 100 & 0.013002 & 0.751945 & 0.244123 & 3.379894 \\
18 & 99 & 0.022105 & 1.158016 & 0.271624 & 3.636372 \\
19 & 99 & 0.0044 & 0.296662 & 0.277219 & 3.612289 \\
20 & 98 & 0.005427 & 0.306589 & 0.28415 & 3.590581 \\
21 & 98 & -0.00802 & -0.52733 & 0.273851 & 3.377051 \\
22 & 98 & 0.012019 & 0.556436 & 0.289162 & 3.483879 \\
23 & 98 & 0.014299 & 0.803532 & 0.307596 & 3.624514 \\
24 & 97 & -0.00606 & -0.27326 & 0.299674 & 3.439142 \\
25 & 90 & 0.015477 & 0.867023 & 0.31979 & 3.463671 \\
26 & 85 & 0.03025 & 1.67806 & 0.359714 & 3.712794 \\
27 & 85 & 0.00931 & 0.635114 & 0.372373 & 3.771605 \\
28 & 84 & -0.00174 & -0.10695 & 0.369982 & 3.658158 \\
29 & 82 & 0.011344 & 0.652012 & 0.385524 & 3.700668 \\
30 & 79 & 0.017296 & 0.8477 & 0.409487 & 3.793277 \\
31 & 78 & -0.02794 & -1.38525 & 0.370107 & 3.351313 \\
32 & 77 & 0.005137 & 0.37477 & 0.377145 & 3.33964 \\
33 & 74 & 0.046734 & 2.207698 & 0.441504 & 3.774112 \\
34 & 73 & -0.00271 & -0.1694 & 0.437592 & 3.660268 \\
35 & 73 & -0.0103 & -0.44402 & 0.422779 & 3.485479 \\
36 & 72 & -0.03403 & -1.85033 & 0.37436 & 3.022223 \\
\hline & & & & & \\
& & & & & \\
& & & &
\end{tabular}


Table-4c: Average Monthly Returns of Developed Country Companies Average Monthly Retums and Cumulative Retums were calculated only for DevelopedCountry compenies. T-statistic for the raw and abnomal retums are computed as $R t . n_{t} / s d_{t}$ where Rt is the average raw retum formonth $\mathrm{t}\left(\mathrm{AR}\right.$ for abnomal retum) $\mathrm{n}_{\mathrm{t}}$ is the number of observations im montht and $s d_{t}$ is the cross-sectional standard deviation of returns formontht T-statistics for the cumulative average retum (or Cumulative $A$ verage $A$ bnomal Retum CAR) in montht $\mathrm{CR}_{\text {, }}$, s computed as $\mathrm{C}_{t}$, nt $/ \mathrm{cs} d t$ wherecsdt iscomputedas $c s d t=[t . v a r+2 .(t-1) . c o v]^{] / 2}$, wherevar is the average crosssectional variance, and $c o v$ is the first-order autocovariance of the Rerries in particular month.

\begin{tabular}{rrrrrr}
\hline Month & Firms & AR & \multicolumn{2}{c}{ t-Value } & \multicolumn{2}{c}{ trvalue } \\
\hline 1 & 36 & 0.045472 & 1.975725 & 0.045472 & 3.081546 \\
2 & 36 & 0.012414 & 1.174784 & 0.058451 & 2.785942 \\
3 & 36 & 0.064474 & 2.177643 & 0.126693 & 4.92175 \\
4 & 36 & 0.032069 & 2.190323 & 0.162825 & 5.473105 \\
5 & 36 & 0.01452 & 1.448138 & 0.179709 & 5.400037 \\
6 & 36 & 0.036144 & 2.528768 & 0.222348 & 6.097012 \\
7 & 36 & 0.021561 & 1.605899 & 0.248703 & 6.312214 \\
8 & 36 & 0.022951 & 1.204993 & 0.277361 & 6.583692 \\
9 & 36 & 0.008974 & 0.683221 & 0.288824 & 6.462746 \\
10 & 36 & -0.00487 & -0.30179 & 0.282542 & 5.997032 \\
11 & 36 & 0.011941 & 1.136354 & 0.297856 & 6.027293 \\
12 & 36 & 0.015596 & 0.941212 & 0.318098 & 6.162359 \\
13 & 36 & 0.015977 & 1.49992 & 0.339156 & 6.312132 \\
14 & 36 & 0.000941 & 0.085877 & 0.340416 & 6.104762 \\
15 & 34 & 0.04781 & 2.887743 & 0.404502 & 6.810265 \\
16 & 34 & 0.034614 & 2.427732 & 0.453117 & 7.386187 \\
17 & 33 & 0.000122 & 0.00976 & 0.453294 & 7.061977 \\
18 & 33 & -0.00203 & -0.11101 & 0.450345 & 6.818122 \\
19 & 33 & 0.018345 & 1.638105 & 0.476952 & 7.028134 \\
20 & 32 & -0.01263 & -0.99222 & 0.4583 & 6.481609 \\
21 & 30 & 0.023222 & 1.482028 & 0.492165 & 6.576941 \\
22 & 30 & 0.022876 & 1.729947 & 0.5263 & 6.871237 \\
23 & 30 & 0.016783 & 1.275549 & 0.551916 & 7.047143 \\
24 & 30 & 0.021403 & 1.52906 & 0.585132 & 7.31381 \\
25 & 29 & 0.015243 & 1.145044 & 0.609293 & 7.336395 \\
26 & 29 & 0.025134 & 1.591153 & 0.649742 & 7.671376 \\
27 & 29 & 0.018998 & 1.103368 & 0.681083 & 7.890976 \\
28 & 29 & 0.009024 & 0.626209 & 0.696253 & 7.921274 \\
29 & 29 & 0.011273 & 0.575583 & 0.715375 & 7.997158 \\
30 & 29 & 0.020218 & 1.792678 & 0.750056 & 8.243825 \\
31 & 29 & 0.01268 & 0.980557 & 0.772246 & 8.349601 \\
32 & 29 & -0.00185 & -0.12593 & 0.768972 & 8.183173 \\
33 & 29 & -0.00261 & -0.14264 & 0.764348 & 8.009701 \\
34 & 29 & -0.00357 & -0.22093 & 0.758055 & 7.825991 \\
35 & 29 & -0.01647 & -0.9178 & 0.729095 & 7.418636 \\
36 & 29 & -0.01316 & -0.87909 & 0.70634 & 7.086517 \\
\hline & & & & &
\end{tabular}


Table-5a: Average Monthly Abnormal Returns and Cumulative Abnormal Returns adjusted for Local Index

The average returns include all companies in the sample. The average abnomal monthly returns were calculated by subtracting local MSCI dollar index retums from each compeny monthly retums. Tstatistic for theraw and abnomal retums are computed as $R t . n_{t} / s d_{t}$ where Rt is the averageraw retum formonth $\mathrm{t}\left(\mathrm{AR}_{\mathrm{f}} \text { for abnomal retum }\right)_{\mathrm{n}} \mathrm{n}$ is the number of observations in montht and $s d_{t}$ is the crosssectional standard deviation of retums for month $t$ T-statistics for the cumulative average retum (or Cumulative Average Abnomal RetumCAR)inmontht, $\mathrm{CR}_{3}$, is computed as $C R_{t} . n t / \mathrm{cs} d t$ wherecsdt is computedas cs $d t=[t \cdot v a r+2 .(t-1) \cdot \operatorname{cov}]^{1 / 2}$, wherevar is the average cross-sectional variance, and $\operatorname{cov}$ is the first-onder autocovariance of the R series in particularmonth.

\begin{tabular}{rrrrrr}
\hline Month & \multicolumn{1}{l}{ Firms } & AR & \multicolumn{2}{c}{ t-Value } & \multicolumn{2}{c}{ CAR } & \multicolumn{2}{c}{-value } \\
\hline 1 & 143 & 0.019144 & 1.411197 & 0.019144 & 1.77918 \\
2 & 143 & 0.029249 & 2.20891 & 0.048953 & 3.219484 \\
3 & 143 & 0.015111 & 1.102446 & 0.064803 & 3.480752 \\
4 & 143 & 0.006228 & 0.673121 & 0.071435 & 3.323331 \\
5 & 143 & -0.01342 & -1.68172 & 0.057053 & 2.37421 \\
6 & 143 & 0.017113 & 1.88884 & 0.075142 & 2.854696 \\
7 & 143 & -0.00794 & -0.77525 & 0.066605 & 2.342738 \\
8 & 143 & -0.01136 & -1.033 & 0.054485 & 1.792718 \\
9 & 143 & 0.007465 & 0.692064 & 0.062357 & 1.934428 \\
10 & 143 & 0.000367 & 0.032551 & 0.062747 & 1.846669 \\
11 & 143 & 0.02671 & 1.698237 & 0.091133 & 2.5573 \\
12 & 143 & 0.004695 & 0.473839 & 0.096256 & 2.586099 \\
13 & 142 & 0.008402 & 0.9736 & 0.105467 & 2.712887 \\
14 & 142 & 0.000527 & 0.04957 & 0.10605 & 2.628669 \\
15 & 137 & 0.021698 & 1.737848 & 0.130048 & 3.058926 \\
16 & 135 & -0.00756 & -0.58929 & 0.121503 & 2.746926 \\
17 & 133 & 0.014405 & 1.466467 & 0.137659 & 2.996821 \\
18 & 132 & 0.012081 & 1.060433 & 0.151404 & 3.191124 \\
19 & 132 & -0.00385 & -0.37901 & 0.146966 & 3.014997 \\
20 & 130 & -0.01023 & -0.83759 & 0.135235 & 2.683528 \\
21 & 128 & 0.008911 & 0.737775 & 0.145351 & 2.793033 \\
22 & 128 & 0.001204 & 0.094532 & 0.146731 & 2.754723 \\
23 & 128 & 0.005304 & 0.522167 & 0.152813 & 2.805864 \\
24 & 127 & 0.000306 & 0.029056 & 0.153166 & 2.742363 \\
25 & 119 & 0.003417 & 0.297516 & 0.157107 & 2.667876 \\
26 & 114 & 0.000676 & 0.059298 & 0.157889 & 2.573265 \\
27 & 114 & 0.01863 & 1.716212 & 0.17946 & 2.870166 \\
28 & 113 & -0.00099 & -0.11126 & 0.178297 & 2.787875 \\
29 & 111 & 0.021214 & 1.996869 & 0.203294 & 3.095686 \\
30 & 108 & -0.01995 & -1.80943 & 0.179282 & 2.647642 \\
31 & 107 & -0.0013 & -0.11814 & 0.177747 & 2.570309 \\
32 & 106 & -0.0123 & -1.20881 & 0.163261 & 2.31277 \\
33 & 103 & 0.013141 & 0.917605 & 0.178548 & 2.455214 \\
34 & 102 & -0.0063 & -0.63103 & 0.171122 & 2.306965 \\
35 & 102 & 0.011164 & 0.769773 & 0.184196 & 2.447492 \\
36 & 101 & -0.01484 & -1.30945 & 0.166627 & 2.17235 \\
\hline & & & & & \\
& & & & & \\
& 143 &
\end{tabular}


Table-5b: Average Abnormal Monthly Returns and Cumulative Abnormal Returns adjusted for Local Index-Emerging Market Companies The average monthly retums RandCumulative Retums(CR) were calculated for only emerging market companies. Theaverage retums inchuleall companies in the sample. The average abnormal monthly returns were calculated by subtracting local MSCI dollar index returns from each company monthly retums. T-statistic for the raw and abnomal retums are computed as $R t . n_{t} / s d_{t}$ where Rt is the average raw retum for month $t$ ( $A R_{t}$ for abnormal retum), $n$ is the number of observations in montht and $s d_{t}$ is the cross-sectional standard deviation of returns for montht. T-statistics for the cumulative average retum(orCumulative Average Abnomal RetumCAR)inmontht, $\mathrm{CR}$, iscomputedas $C R_{t}, n t / c s d t$ wherecsdt is computedas $c s d t=[t . v a r+2 .(t-l) . c o v]^{1 / 2}$, wherevar is the averagecross-sectional variance, and cov is the first-onder autocovariance of the Rseries in particular month

\begin{tabular}{|c|c|c|c|c|c|c|}
\hline Month & Firms & AR & & t-Value & CAR & $\mathrm{t}$-value \\
\hline 1 & 1 & 107 & 0.014236 & 0.844039 & 0.014236 & 1.036786 \\
\hline 2 & 2 & 107 & 0.035496 & 2.052348 & 0.050238 & 2.592474 \\
\hline 3 & 3 & 107 & 0.002368 & 0.15376 & 0.052725 & 2.223082 \\
\hline 4 & 4 & 107 & 0.005298 & 0.451532 & 0.058302 & 2.129659 \\
\hline 5 & 5 & 107 & -0.01475 & -1.42913 & 0.04269 & 1.395042 \\
\hline 6 & 6 & 107 & 0.018557 & 1.606523 & 0.062039 & 1.850965 \\
\hline 7 & 7 & 107 & -0.01385 & -1.06336 & 0.047332 & 1.307547 \\
\hline 8 & 8 & 107 & $-0,02234$ & -1.66166 & 0.023937 & 0.618592 \\
\hline 9 & 9 & 107 & 0.006828 & 0.487694 & 0.030928 & 0.753592 \\
\hline 10 & & 107 & 0.000387 & 0.026986 & 0.031326 & 0.724165 \\
\hline 11 & & 107 & 0.033023 & 1.598432 & 0.065384 & 1.441187 \\
\hline 12 & & 107 & 0.001654 & 0.132394 & 0.067147 & 1.417072 \\
\hline 13 & & 106 & 0.010953 & 0.993789 & 0.078835 & 1.591031 \\
\hline 14 & & 106 & 0.004757 & 0.343089 & 0.083968 & 1.633006 \\
\hline 15 & & 103 & 0.019866 & 1.243543 & 0.105502 & 1.954019 \\
\hline 16 & & 101 & -0.0199 & -1.20748 & 0.083499 & 1.482803 \\
\hline 17 & & 100 & 0.018366 & 1.436447 & 0.103398 & 1.772543 \\
\hline 18 & & 99 & 0.021154 & 1.508295 & 0.126738 & 2.100905 \\
\hline 19 & & 99 & -0.00767 & -0.58768 & 0.118094 & 1.905419 \\
\hline 20 & & 98 & -0.00568 & -0.35662 & 0.111738 & 1.74834 \\
\hline 21 & & 98 & 0.008213 & 0.537945 & 0.120868 & 1.84564 \\
\hline 22 & & 98 & 0.003339 & 0.202419 & 0.124611 & 1.859056 \\
\hline 23 & & 98 & 0.003952 & 0.308059 & 0.129055 & 1.883055 \\
\hline 24 & & 97 & -0.00014 & -0.01043 & 0.128897 & 1.831747 \\
\hline 25 & & 90 & 0.00273 & 0.18421 & 0.131979 & 1.770114 \\
\hline 26 & & 85 & -0.00432 & -0.29818 & 0.127084 & 1.624279 \\
\hline 27 & & 85 & 0.021993 & 1.602524 & 0.151871 & 1.90482 \\
\hline 28 & & 84 & -0.006 & -0.53146 & 0.144963 & 1.774891 \\
\hline 29 & & 82 & 0.026502 & 1.995484 & 0.175308 & 2.083836 \\
\hline 30 & & 79 & $-0,03064$ & -2.14031 & 0.139299 & 1.597931 \\
\hline 31 & & 78 & 0.005484 & 0.37974 & 0.145547 & 1.632032 \\
\hline 32 & & 77 & -0.00777 & -0.58632 & 0.13665 & 1.498449 \\
\hline 33 & & 74 & 0.025952 & 1.359792 & 0.166149 & 1.758809 \\
\hline 34 & & 73 & -0.00999 & -0.78022 & 0.154502 & 1.600368 \\
\hline 35 & & 73 & 0.013178 & 0.687496 & 0.169716 & 1.732669 \\
\hline 36 & & 72 & -0.01675 & -1.08688 & 0.150125 & 1.500845 \\
\hline
\end{tabular}


Table-5c: Average Abnormal Monthly Returns and Cumulative Abnormal Returns adjusted for Local Index-Developed Country Companies The averagemonthly retums RandCumulative Retums(CR) were calculated for only Developod Country companies The average returns inchude all compamies in the sample. The average abnormal monthly returns were calculated by subtracting local MSCI dollar index retums from each compeny monthly retums. T-statistic for the raw and abnomal retums are computed as $R t . n_{t} / s d_{t}$ where Rt is the average rawnetum formonth $t\left(A R_{i}\right.$ for abnormal retum) $n_{t}$ is the number of observations in montht and $s d_{l}$ is the cross-sectional standard deviation of retums formontht $\mathrm{T}$-statistics for thecumulative average retum(or Cumulative Average Abnomal Retum CAR)inmonth $\mathrm{CR}_{\text {, }}$, iscomputed as $C R_{t}, n t$ $/ c s d t$ wherecsdt is computedas $\operatorname{cs} d t=[t \cdot v a r+2 .(t-1) \cdot \operatorname{cov}]^{I / 2}$, wherevar is the averagecrosssectional variance, and cov is the first-order autocovariance of the Reries in particular month.

\begin{tabular}{rrrrrr}
\hline Month & Firms & AR & \multicolumn{2}{c}{ t-Value } & \multicolumn{2}{c}{ CAR -value } \\
\hline 1 & 36 & 0.03373 & 1.693386 & 0.03373 & 2.613499 \\
2 & 36 & 0.01068 & 0.975785 & 0.04477 & 2.442414 \\
3 & 36 & 0.052986 & 1.830259 & 0.100128 & 4.453708 \\
4 & 36 & 0.008992 & 0.760022 & 0.11002 & 4.235063 \\
5 & 36 & -0.00947 & -1.15745 & 0.099505 & 3.424464 \\
6 & 36 & 0.012822 & 1.164913 & 0.113603 & 3.567994 \\
7 & 36 & 0.009617 & 0.779057 & 0.124312 & 3.614004 \\
8 & 36 & 0.021258 & 1.264489 & 0.148213 & 4.029928 \\
9 & 36 & 0.00936 & 0.889271 & 0.15896 & 4.074488 \\
10 & 36 & 0.000309 & 0.021701 & 0.159319 & 3.873755 \\
11 & 36 & 0.007946 & 0.694011 & 0.168531 & 3.906739 \\
12 & 36 & 0.013733 & 1.041979 & 0.184579 & 4.096327 \\
13 & 36 & 0.00089 & 0.08559 & 0.185634 & 3.9579 \\
14 & 36 & -0.01193 & -1.24221 & 0.171491 & 3.523189 \\
15 & 34 & 0.027192 & 1.912924 & 0.203346 & 3.922117 \\
16 & 34 & 0.028737 & 2.270985 & 0.237927 & 4.443227 \\
17 & 33 & 0.002525 & 0.30357 & 0.241053 & 4.302358 \\
18 & 33 & -0.01486 & -0.87231 & 0.22261 & 3.861147 \\
19 & 33 & 0.007486 & 0.67005 & 0.231762 & 3.912573 \\
20 & 32 & -0.024 & -2.62855 & 0.202199 & 3.276183 \\
21 & 30 & 0.01117 & 0.823729 & 0.215627 & 3.301227 \\
22 & 30 & -0.0057 & -0.70966 & 0.208701 & 3.121672 \\
23 & 30 & 0.009677 & 0.840904 & 0.220398 & 3.224105 \\
24 & 30 & 0.001734 & 0.157261 & 0.222513 & 3.186469 \\
25 & 29 & 0.005479 & 0.481646 & 0.229211 & 3.161974 \\
26 & 29 & 0.014843 & 1.023173 & 0.247456 & 3.347328 \\
27 & 29 & 0.009102 & 0.617112 & 0.258811 & 3.435432 \\
28 & 29 & 0.013044 & 1.153233 & 0.275231 & 3.58752 \\
29 & 29 & 0.006761 & 0.427363 & 0.283853 & 3.635517 \\
30 & 29 & 0.008176 & 0.675355 & 0.294349 & 3.706549 \\
31 & 29 & -0.01894 & -1.55833 & 0.269829 & 3.342497 \\
32 & 29 & -0.02394 & -1.91822 & 0.239434 & 2.919242 \\
33 & 29 & -0.01846 & -1.31306 & 0.216556 & 2.59998 \\
34 & 29 & 0.002671 & 0.186502 & 0.219806 & 2.599877 \\
35 & 29 & 0.006262 & 0.358891 & 0.227444 & 2.651496 \\
36 & 29 & -0.01031 & -0.95057 & 0.214787 & 2.468901 \\
\hline & & & & & \\
& & & & & \\
& 36 &
\end{tabular}


Table-6a: Average Monthly Abnormal Returns and Cumulative Abnormal Returns adjusted for S\&P500 Index.

The average retums inchide all companies in the sample. The average abnomal monthly retums were calculated by subtracting S\&P500 index retums from each compeny monthly retums. T-statistic for the raw and abnomal returns are computedas $R t . n_{t} / s d_{t}$ where $R t$ is the average raw retum for month $t\left(\mathrm{AR}_{t}\right.$ for abnomal retum), $\mathbf{n}_{i}$ is thenumber of observations in month $t$ and $s d_{t}$ is the cross-sectional standard deviation of retums formontht. T-statistics for the cumulative average retum (or Cumulative Average Abnomal RetumCAR)inmontht, $\mathrm{CR}_{t}$ is computed as $C R_{t}$. nt $/ \mathrm{cs} d t$ where csdt is computedas csdt = $[t \cdot v a r+2 .(t-1) \cdot \operatorname{cov}]^{1 / 2}$, wherevar is the average cross-sectional variance, and cov is the first-order autocovariance of the R series in perticularmonth.

\begin{tabular}{|c|c|c|c|c|c|c|}
\hline Month & Firms & & $\overline{\mathrm{AR}}$ & t-Value & CAR & t-value \\
\hline 1 & 1 & 143 & 0.002787 & 0.18671 & 0.002787 & 0.214613 \\
\hline 2 & 1 & 143 & 0.01614 & 0.98539 & 0.018972 & 1.032455 \\
\hline 3 & 1. & 143 & 0.007901 & 0.53506 & 0.027023 & 1.200493 \\
\hline 4 & 1. & 143 & 0.013621 & 1.201385 & 0.041012 & 1.577724 \\
\hline 5 & 1. & 143 & -0.01151 & -0.97196 & 0.029028 & 0.998737 \\
\hline 6 & 1 & 143 & 0.00981 & 0.869371 & 0.039123 & 1.228733 \\
\hline 7 & 1 & 143 & -0.01527 & -1.29547 & 0.023254 & 0.676148 \\
\hline 8 & 14 & 143 & -0.00865 & -0.64014 & 0.014405 & 0.391778 \\
\hline 9 & 1 & 143 & -0.01005 & -0.84152 & 0.004206 & 0.107851 \\
\hline 10 & & 143 & -0.02528 & -2.07809 & -0.02118 & -0.51528 \\
\hline 11 & & 143 & 0.009231 & 0.542715 & -0.01215 & -0.28172 \\
\hline 12 & & 143 & 0.000594 & 0.047579 & -0.01156 & -0.2567 \\
\hline 13 & & 142 & 0.008479 & 0.683817 & -0.00318 & -0.06758 \\
\hline 14 & & 142 & -0.00839 & -0.67444 & -0.01154 & -0.23638 \\
\hline 15 & & 137 & 0.019035 & 1.15007 & 0.007278 & 0.141478 \\
\hline 16 & & 135 & -0.00157 & -0.12204 & 0.005701 & 0.106519 \\
\hline 17 & & 133 & -0.01172 & -0.89132 & -0.00609 & -0.1095 \\
\hline 18 & & 132 & 0.003022 & 0.196643 & -0.00308 & -0.05369 \\
\hline 19 & & 132 & -0.0075 & -0.65948 & -0.01056 & -0.17897 \\
\hline 20 & & 130 & -0.01194 & -0.90265 & -0.02237 & -0.36687 \\
\hline 21 & & 128 & -0.01507 & -1.24198 & -0.0371 & -0.5892 \\
\hline 22 & & 128 & 0.001051 & 0.063244 & -0.03609 & -0.55994 \\
\hline 23 & & 128 & 0.002546 & 0.186919 & -0.03363 & -0.51039 \\
\hline 24 & & 127 & -0.01327 & -0.83032 & -0.04646 & -0.6875 \\
\hline 25 & & 119 & -0.00307 & -0.22269 & -0.04939 & -0.69312 \\
\hline 26 & & 114 & 0.010727 & 0.794212 & -0.03919 & -0.52788 \\
\hline 27 & & 114 & -0.00215 & -0.17945 & -0.04126 & -0.54531 \\
\hline 28 & & 113 & -0.00673 & -0.5481 & -0.04771 & -0.61655 \\
\hline 29 & & 111 & -0.00122 & -0.083 & -0.04888 & -0.61507 \\
\hline 30 & 10 & 108 & 0.000719 & 0.046993 & -0.04819 & -0.58816 \\
\hline 31 & & 107 & -0.03385 & -2.50128 & -0.08041 & -0.96092 \\
\hline 32 & & 106 & -0.01471 & -1.33221 & -0.09394 & -1.09972 \\
\hline 33 & & 103 & 0.017056 & 1.026635 & -0.07848 & -0.89188 \\
\hline 34 & & 102 & -0.01434 & -1.19763 & -0.0917 & -1.02159 \\
\hline 35 & 10 & 102 & -0.02884 & -1.69233 & -0.11789 & -1.2945 \\
\hline 36 & & 101 & -0.03787 & -2.71159 & -0.15129 & -1.63003 \\
\hline
\end{tabular}


Table-6b: Average Abnormal Monthly Returns and Cumulative Abnormal Returns adjusted for S\&P500-Emerging Market Companies

The average monthly retums R and Cumulative Retums(CR) were calculated for only emerging market companies. Theaverageretums include all companies in the sample. The average abnomal monthly retums were calculated by subtracting S\&P500 index retums from each company monthly retums. Tstatistic for the raw and abnomal retums are computed as $R t . n_{t} / s d_{t}$ where Rt is the average raw retum formonth $\mathrm{t}\left(\mathrm{AR}\right.$ for abnomal retum), $\mathrm{n}$ is the number of observations in montht, and $s d_{t}$ is the crosssectional standard deviation of returns for montht. T-statistics for the cumulative average retum (or Cumulative Average Abnomal Retum CAR) inmontht $C R$, iscomputed as $\left(R_{t}, n t / c s d t\right.$ where csdt is computedas $c s d t=[t \cdot v a r+2 .(t-1) \cdot \operatorname{cov}]^{1 / 2}$, where $v a r$ is the average cross-sectional variance, and $c o v$ is the first-order autocovariance of the Reries in particular mont

\begin{tabular}{rrrrrr}
\hline Month & Firms & AR & \multicolumn{2}{c}{ t-value } & \multicolumn{2}{c}{ CAR } & \multicolumn{2}{c}{-value } \\
\hline 1 & 107 & -0.00449 & -0.24258 & -0.00449 & -0.26933 \\
2 & 107 & 0.023195 & 1.075153 & 0.018603 & 0.789513 \\
3 & 107 & -0.00506 & -0.30686 & 0.013448 & 0.466007 \\
4 & 107 & 0.012976 & 0.905481 & 0.026599 & 0.798228 \\
5 & 107 & -0.0149 & -0.96461 & 0.011306 & 0.30346 \\
6 & 107 & 0.010632 & 0.735132 & 0.022057 & 0.540469 \\
7 & 107 & -0.02176 & -1.44017 & -0.00018 & -0.00416 \\
8 & 107 & -0.01457 & -0.87564 & -0.01475 & -0.3131 \\
9 & 107 & -0.01155 & -0.74981 & -0.02613 & -0.52287 \\
10 & 107 & -0.03234 & -2.09737 & -0.05763 & -1.0938 \\
11 & 107 & 0.007584 & 0.339492 & -0.05048 & -0.91357 \\
12 & 107 & 0.002384 & 0.150293 & -0.04822 & -0.83545 \\
13 & 106 & 0.012655 & 0.787967 & -0.03617 & -0.59935 \\
14 & 106 & -0.00156 & -0.09666 & -0.03767 & -0.60148 \\
15 & 103 & 0.015566 & 0.729777 & -0.02269 & -0.34504 \\
16 & 101 & -0.01128 & -0.68503 & -0.03372 & -0.49153 \\
17 & 100 & -0.01091 & -0.63486 & -0.04426 & -0.62281 \\
18 & 99 & 0.006708 & 0.347447 & -0.03785 & -0.51499 \\
19 & 99 & -0.01114 & -0.75608 & -0.04856 & -0.6432 \\
20 & 98 & -0.00693 & -0.40409 & -0.05516 & -0.70842 \\
21 & 98 & -0.0201 & -1.31488 & -0.07415 & -0.92938 \\
22 & 98 & 0.002823 & 0.130938 & -0.07153 & -0.876 \\
23 & 98 & 0.003292 & 0.190414 & -0.06848 & -0.82013 \\
24 & 97 & -0.01731 & -0.84205 & -0.0846 & -0.98685 \\
25 & 90 & -0.00512 & -0.2876 & -0.08929 & -0.98301 \\
26 & 85 & 0.011702 & 0.672023 & -0.07863 & -0.82496 \\
27 & 85 & -0.00628 & -0.4169 & -0.08442 & -0.86907 \\
28 & 84 & -0.01146 & -0.71512 & -0.09491 & -0.95381 \\
29 & 82 & -0.00099 & -0.05309 & -0.09581 & -0.93476 \\
30 & 79 & 0.004443 & 0.216898 & -0.09179 & -0.86426 \\
31 & 78 & -0.04133 & -2.30118 & -0.12932 & -1.19028 \\
32 & 77 & -0.01225 & -0.86579 & -0.13999 & -1.26 \\
33 & 74 & 0.031678 & 1.451353 & -0.11275 & -0.97964 \\
34 & 73 & -0.0175 & -1.09898 & -0.12827 & -1.09059 \\
35 & 73 & -0.03247 & -1.42865 & -0.15658 & -1.3121 \\
36 & 72 & -0.03992 & -2.13458 & -0.19025 & -1.56117 \\
\hline & & & & &
\end{tabular}


Table-6c: Average Abnormal Monthly Returns and Cumulative Abnormal Returns adjusted for S\&P500 Index-Developed Country Companies The average monthly retums RandCumulative Retums(CR) werecalculated for only Developed Country compenies The averageretums include all compemies in the sample. The average abnomal monthly retums were calculated by subtracting S\&P500 index retums from each company monthly retums. T-statistic for the raw and abnomal retums are computedas $R t . n_{t} / s d_{t}$ where Rt is the average raw retum formonth $\mathrm{t}\left(\mathrm{AR}\right.$ for abnomal retum), $n$ is the number of observations in montht, and $s d_{t}$ is the cross-sectional standard deviation of returns formontht. T-statistics for the cumulative average retum (orCumulative Average Abnomal RetumCAR) inmonth $\mathrm{CR}_{\mathrm{s}}$, iscomputed as $\mathrm{CR}_{t}$. nt / csdt where csdt is computedas $c s d t=[t . v a r+2 .(t-1) . \operatorname{cov}]^{1 / 2}$, wherevar is the average cross-sectional variance, and cov is the first-order autocovariance of the Reries in particularmonth.

\begin{tabular}{rrrrrr}
\hline Month & Firms & AR & \multicolumn{2}{c}{ t-value } & \multicolumn{2}{c}{ CAR } \\
\hline 1 & 36 & 0.024408 & 1.099714 & 0.024408 & 1.635504 \\
2 & 36 & -0.00483 & -0.44524 & 0.019464 & 0.919176 \\
3 & 36 & 0.046426 & 1.461515 & 0.066793 & 2.572677 \\
4 & 36 & 0.015538 & 1.040834 & 0.083369 & 2.779419 \\
5 & 36 & -0.00145 & -0.13841 & 0.081796 & 2.438274 \\
6 & 36 & 0.007368 & 0.566617 & 0.089767 & 2.442207 \\
7 & 36 & 0.004017 & 0.307998 & 0.094145 & 2.370951 \\
8 & 36 & 0.008964 & 0.429225 & 0.103952 & 2.448576 \\
9 & 36 & -0.0056 & -0.43848 & 0.097765 & 2.170945 \\
10 & 36 & -0.0043 & -0.28479 & 0.093042 & 1.959888 \\
11 & 36 & 0.014128 & 1.084806 & 0.108484 & 2.178695 \\
12 & 36 & -0.00473 & -0.30361 & 0.103243 & 1.985081 \\
13 & 36 & -0.00382 & -0.30299 & 0.099031 & 1.829314 \\
14 & 36 & -0.0285 & -2.29593 & 0.06771 & 1.205215 \\
15 & 34 & 0.029442 & 1.72027 & 0.099146 & 1.656833 \\
16 & 34 & 0.027005 & 1.993804 & 0.128829 & 2.084444 \\
17 & 33 & -0.01416 & -1.3336 & 0.11285 & 1.745105 \\
18 & 33 & -0.00792 & -0.37636 & 0.104032 & 1.563381 \\
19 & 33 & 0.003319 & 0.301385 & 0.107696 & 1.575253 \\
20 & 32 & -0.02713 & -2.31838 & 0.077641 & 1.089966 \\
21 & 30 & 0.001201 & 0.087178 & 0.078935 & 1.047074 \\
22 & 30 & -0.00468 & -0.4815 & 0.073888 & 0.957574 \\
23 & 30 & 0.000132 & 0.009225 & 0.07403 & 0.938316 \\
24 & 30 & -0.00036 & -0.02678 & 0.073645 & 0.913764 \\
25 & 29 & 0.003094 & 0.234542 & 0.076967 & 0.919955 \\
26 & 29 & 0.007967 & 0.509298 & 0.085547 & 1.002639 \\
27 & 29 & 0.009543 & 0.56406 & 0.095906 & 1.103029 \\
28 & 29 & 0.006496 & 0.522251 & 0.103025 & 1.163541 \\
29 & 29 & -0.00182 & -0.08802 & 0.101012 & 1.12096 \\
30 & 29 & -0.00909 & -0.69872 & 0.091008 & 0.992963 \\
31 & 29 & -0.0144 & -1.10177 & 0.075297 & 0.808178 \\
32 & 29 & -0.02102 & -1.37543 & 0.052696 & 0.556684 \\
33 & 29 & -0.01901 & -1.00735 & 0.03268 & 0.339962 \\
34 & 29 & -0.00664 & -0.48796 & 0.02582 & 0.264613 \\
35 & 29 & -0.01999 & -1.05474 & 0.005314 & 0.053674 \\
36 & 29 & -0.03301 & -2.10997 & -0.02787 & -0.27756 \\
\hline & & & & & \\
& & & & & \\
& 36 &
\end{tabular}


Table-7a: Average Monthly Abnormal Returns and Cumulative Abnormal Returns adjusted for Financial Times World Index.

Theaverage retums inchideall companies in the sample. The average abnomal monthly retums were calculated by subtracting FTWorddindex retumn from each compeny monthly returns. T-statistic for the raw and abnomal returns are computedas $R t . n_{t} / s d_{t}$ where $R t$ is the average raw return for month $t\left(\mathrm{AR}_{t}\right.$ forabnomal return), $n_{i}$ is thenumber of observations in montht, and $s d_{t}$ is the cross-sectional standard deviation of retums formontht. T-statistics for the cumulative average retum (or Cumulative Average Abnomal RetumCAR)inmontht, $\mathrm{CR}_{t}$ is computed as $\mathrm{CR}_{t} . n t / \operatorname{cs} d t$ where csdt is computed as $\operatorname{cs} d t=$ $[t \cdot v a r+2 .(t-1) \cdot \operatorname{cov}]^{1 / 2}$, wherevar is the average cross-sectional variance, and cov is the first-order autocovariance of the R series in perticularmonth.

\begin{tabular}{|c|c|c|c|c|c|c|}
\hline Month & Firms & & $\overline{\mathrm{AR}}$ & $\mathrm{t}$-value & CAR & t-value \\
\hline 1 & 1 & 143 & 0.023725 & 1.368325 & 0.023725 & 1.619109 \\
\hline 2 & 1 & 143 & 0.01177 & 0.824628 & 0.035774 & 1.726575 \\
\hline 3 & 3 & 143 & 0.021686 & 1.825831 & 0.058236 & 2.295001 \\
\hline 4 & 4 & 143 & -0.00698 & -0.60257 & 0.050845 & 1.735322 \\
\hline 5 & 5 & 143 & 0.020484 & 1.701599 & 0.07237 & 2.20924 \\
\hline 6 & 6 & 143 & -0.01372 & -1.20904 & 0.057657 & 1.606768 \\
\hline 7 & 7 & 143 & 0.002583 & 0.178708 & 0.060389 & 1.558073 \\
\hline 8 & 8 & 143 & -0.01283 & -0.98602 & 0.046789 & 1.129211 \\
\hline 9 & 9 & 143 & -0.02638 & -2.04819 & 0.019176 & 0.436334 \\
\hline 10 & & 143 & 0.012708 & 0.731425 & 0.032128 & 0.693529 \\
\hline 11 & & 143 & 0.019957 & 1.461 & 0.052726 & 1.085202 \\
\hline 12 & & 143 & 0.008431 & 0.653648 & 0.061601 & 1.213893 \\
\hline 13 & & 142 & 0.003054 & 0.243489 & 0.064843 & 1.223359 \\
\hline 14 & & 142 & 0.020731 & 1.274436 & 0.086918 & 1.580188 \\
\hline 15 & & 137 & -0.00197 & -0.15597 & 0.084775 & 1.462507 \\
\hline 16 & & 135 & 0.001464 & 0.107325 & 0.086363 & 1.432032 \\
\hline 17 & & 133 & -0.00025 & -0.01656 & 0.086088 & 1.374558 \\
\hline 18 & & 132 & 0.000778 & 0.063482 & 0.086933 & 1.343859 \\
\hline 19 & & 132 & -0.00707 & -0.50196 & 0.079249 & 1.192407 \\
\hline 20 & & 130 & -0.00914 & -0.73858 & 0.069382 & 1.009774 \\
\hline 21 & & 128 & 0.005621 & 0.329574 & 0.075393 & 1.062544 \\
\hline 22 & & 128 & 0.002513 & 0.173995 & 0.078095 & 1.075323 \\
\hline 23 & & 128 & -0.00888 & -0.49392 & 0.068521 & 0.922755 \\
\hline 24 & & 127 & 0.003129 & 0.231201 & 0.071865 & 0.943697 \\
\hline 25 & & 119 & 0.018749 & 1.383838 & 0.091961 & 1.145322 \\
\hline 26 & & 114 & -0.00158 & -0.12641 & 0.090231 & 1.078554 \\
\hline 27 & & 114 & -0.00404 & -0.31345 & 0.085828 & 1.006746 \\
\hline 28 & & 113 & 0.011276 & 0.784849 & 0.098072 & 1.124668 \\
\hline 29 & & 111 & 0.007969 & 0.527893 & 0.106822 & 1.19301 \\
\hline 30 & & 108 & -0.02953 & -1.90597 & 0.074134 & 0.802952 \\
\hline 31 & & 107 & -0.00987 & -0.82466 & 0.063531 & 0.673775 \\
\hline 32 & & 106 & 0.016069 & 0.990893 & 0.080621 & 0.837617 \\
\hline 33 & & 103 & -0.01382 & -1.08499 & 0.065685 & 0.66244 \\
\hline 34 & & 102 & -0.0185 & -0.99921 & 0.045967 & 0.454498 \\
\hline 35 & & 102 & -0.03992 & -2.95189 & 0.004208 & 0.041011 \\
\hline 36 & & 101 & 0.116556 & 2.374568 & 0.121254 & 1.159388 \\
\hline
\end{tabular}


Table-7b: Average Abnormal Monthly Returns and Cumulative Abnormal Returns adjusted for Financial Times World Index-Emerging Market Companies The average monthly retums $\mathrm{R}$ and Cumulative Retums(CR) were calculated for only emaging market companies. Theaverageretums inchude all companies in the sample. The average abnormal monthly returns were calculated by subtracting FTWorld index retums from each company monthly returns. Tstatistic for the raw and abnormal retums are computed as $R t . n_{t} / s d_{t}$ where Rt is the averageraw retum formonth $\mathrm{t}\left(\mathrm{AR}_{+} \text {for abnomal retum }\right)_{\mathrm{t}}$ is the number of observations in montht, and $s d_{t}$ is the crosssectional standard deviation of retums for montht. T-statistics for the cumulative average retum (or Cumulative Average Abnomal RetumCAR)inmontht, $\mathrm{CR}$, is computed as $C R_{t}, n t /$ cs $d t$ where csatt is computedas $c s d t=[t . v a r+2 .(t-1) . c o v]^{1 / 2}$, where $v a r$ is the average cross-sectional variance, and $\operatorname{cov}$ is the first-onder autocovariance of the $\mathrm{R}$ series in particular mont

\begin{tabular}{|c|c|c|c|c|c|c|}
\hline Month & Firms & AR & & $\mathrm{t}$-value & CAR & $\mathrm{t}$-value \\
\hline 1 & & 107 & 0.000566 & 0.03052 & 0.000566 & 0.030059 \\
\hline 2 & & 107 & 0.029155 & 1.341201 & 0.029738 & 1.117507 \\
\hline 3 & & 107 & 0.00064 & 0.038549 & 0.030397 & 0.933086 \\
\hline 4 & & 107 & 0.015454 & 1.076148 & 0.046321 & 1.231681 \\
\hline 5 & & 107 & -0.01033 & -0.67756 & 0.03551 & 0.844656 \\
\hline 6 & & 107 & 0.014974 & 1.037846 & 0.051016 & 1.10784 \\
\hline 7 & & 107 & -0.01428 & -0.96772 & 0.036002 & 0.723862 \\
\hline 8 & & 107 & $-0,0079$ & -0.48177 & 0.027822 & 0.523289 \\
\hline 9 & & 107 & -0.00692 & -0.44575 & 0.020707 & 0.367198 \\
\hline 10 & & 107 & -0.02603 & -1.69936 & -0.00587 & -0.09868 \\
\hline 11 & & 107 & 0.014233 & 0.641748 & 0.008284 & 0.132888 \\
\hline 12 & & 107 & 0.01162 & 0.749374 & 0.02 & 0.307179 \\
\hline 13 & & 106 & 0.015432 & 0.974992 & 0.035741 & 0.524937 \\
\hline 14 & & 106 & 0.019177 & 0.911362 & 0.055603 & 0.78696 \\
\hline 15 & & 103 & -0.01068 & -0.65949 & 0.044329 & 0.597493 \\
\hline 16 & & 101 & 0.003798 & 0.215606 & 0.048295 & 0.624141 \\
\hline 17 & & 100 & 0.001962 & 0.100686 & 0.050352 & 0.628166 \\
\hline 18 & & 99 & $-0,0051$ & -0.32686 & 0.044995 & 0.542792 \\
\hline 19 & & 99 & -0.00226 & -0.12492 & 0.042638 & 0.500646 \\
\hline 20 & & 98 & -0.01714 & -1.09713 & 0.024762 & 0.281956 \\
\hline 21 & & 98 & 0.005459 & 0.248508 & 0.030356 & 0.337322 \\
\hline 22 & & 98 & 0.005821 & 0.318633 & 0.036354 & 0.394683 \\
\hline 23 & & 98 & -0.01368 & -0.59385 & 0.022178 & 0.235485 \\
\hline 24 & & 97 & 0.004777 & 0.279094 & 0.027061 & 0.279846 \\
\hline 25 & & 90 & 0.018807 & 1.095011 & 0.046377 & 0.452644 \\
\hline 26 & & 85 & -0.00632 & -0.41209 & 0.039769 & 0.369891 \\
\hline 27 & & 85 & -0.00717 & -0.43594 & 0.032317 & 0.294958 \\
\hline 28 & & 84 & 0.008248 & 0.458616 & 0.040831 & 0.363799 \\
\hline 29 & & 82 & 0.007147 & 0.358555 & 0.04827 & 0.417536 \\
\hline 30 & & 79 & -0.0369 & -1.80159 & 0.009588 & 0.080041 \\
\hline 31 & & 78 & -0.00449 & -0.29328 & 0.00506 & 0.041291 \\
\hline 32 & & 77 & 0.031036 & 1.491623 & 0.036253 & 0.289289 \\
\hline 33 & & 74 & -0.01518 & -0.91705 & 0.020523 & 0.158094 \\
\hline 34 & & 73 & -0.01943 & -0.78264 & 0.000695 & 0.005238 \\
\hline 35 & & 73 & -0.04988 & -2.8086 & -0.04922 & -0.36566 \\
\hline 36 & & 72 & 0.078295 & 1.239494 & 0.025222 & 0.183492 \\
\hline
\end{tabular}


Table-7c: Average Abnormal Monthly Returns and Cumulative Abnormal Returns adjusted for Financial Times World Index-Developed Country Companies

The average monthly retums Rand Gumulative Retums(CR) were calculated for only Developed Country companies The average returns inchide all compamies in the sample. The average abnormal monthly returns were calculated by subtracting FTWorld index returns from each company monthly returns. T-statistic for theraw and abnomal retums are computed as $R t . n_{t} / s d_{t}$ where Rt is the average raw retum for month $t$ ( $A R_{t}$ for abnormal retum), $n$ is the number of observations in montht and $s d_{t}$ is the cross-sectional standard deviation of returns for montht T-statistics for the cumulative average retum(orCumulative Average Abnomal RetumCAR)inmonth $\mathrm{CR}_{\text {, }}$, is computed as $C R_{t}$. nt / csdt wherecsdt is computedas $c s d t=[t . v a r+2 .(t-l) . c o v]^{1 / 2}$, wherevar is the averagecross-sectional variance, and cov is the first-order autocovariance of the Reries in particularmonth.

\begin{tabular}{rrrrrr}
\hline Month & \multicolumn{1}{c}{ Firms } & AR & \multicolumn{2}{c}{ t-value } & \multicolumn{2}{c}{ CAR } \\
\hline 1 & 36 & -0.00098 & -0.10771 & -0.00098 & -0.05259 \\
2 & 36 & 0.053431 & 1.81004 & 0.052403 & 2.003556 \\
3 & 36 & 0.018762 & 1.244115 & 0.072148 & 2.254344 \\
4 & 36 & 0.000771 & 0.075555 & 0.072974 & 1.97558 \\
5 & 36 & 0.028683 & 1.762557 & 0.10375 & 2.512912 \\
6 & 36 & -0.0006 & -0.04192 & 0.103092 & 2.279842 \\
7 & 36 & 0.012204 & 0.599837 & 0.116555 & 2.386669 \\
8 & 36 & -0.00186 & -0.13065 & 0.114479 & 2.192984 \\
9 & 36 & -0.012 & -0.6938 & 0.101103 & 1.826126 \\
10 & 36 & 0.020477 & 1.530837 & 0.12365 & 2.118895 \\
11 & 36 & 0.017589 & 0.994305 & 0.143414 & 2.343317 \\
12 & 36 & -0.00143 & -0.11464 & 0.141776 & 2.218022 \\
13 & 36 & -0.01106 & -0.92102 & 0.129153 & 1.941347 \\
14 & 36 & 0.025264 & 1.457709 & 0.157681 & 2.284003 \\
15 & 34 & 0.024151 & 1.816277 & 0.18564 & 2.524682 \\
16 & 34 & -0.0054 & -0.37127 & 0.179238 & 2.360265 \\
17 & 33 & -0.0069 & -0.38302 & 0.171103 & 2.153534 \\
18 & 33 & 0.018233 & 1.250278 & 0.192456 & 2.354079 \\
19 & 33 & -0.02136 & -1.35123 & 0.16698 & 1.988015 \\
20 & 32 & 0.015115 & 0.998772 & 0.184618 & 2.109682 \\
21 & 30 & 0.006146 & 0.464831 & 0.191899 & 2.072103 \\
22 & 30 & -0.00818 & -0.51529 & 0.182145 & 1.921584 \\
23 & 30 & 0.006634 & 0.424254 & 0.189987 & 1.960281 \\
24 & 30 & -0.00214 & -0.13898 & 0.187435 & 1.893253 \\
25 & 30 & 0.018573 & 1.126589 & 0.20949 & 2.07329 \\
26 & 30 & 0.011819 & 0.583253 & 0.223785 & 2.171777 \\
27 & 30 & 0.004826 & 0.300627 & 0.229691 & 2.187444 \\
28 & 30 & 0.019754 & 0.948143 & 0.253983 & 2.37521 \\
29 & 30 & 0.010216 & 0.733813 & 0.266793 & 2.451632 \\
30 & 30 & -0.01013 & -0.66853 & 0.253956 & 2.294459 \\
31 & 30 & -0.02388 & -1.47552 & 0.224016 & 1.991056 \\
32 & 30 & -0.02181 & -1.03175 & 0.19732 & 1.726173 \\
33 & 30 & -0.01093 & -0.63528 & 0.184231 & 1.587066 \\
34 & 30 & -0.01624 & -0.83719 & 0.164993 & 1.400292 \\
35 & 30 & -0.0157 & -0.98603 & 0.146704 & 1.227161 \\
36 & 30 & 0.207106 & 3.103406 & 0.384193 & 3.168798 \\
\hline & & & & & \\
& & & & & \\
& 36 &
\end{tabular}



Table-8a: Average Monthly Returns and Cumulative Abnormal Returns (Benchmark-CI) based on exchange

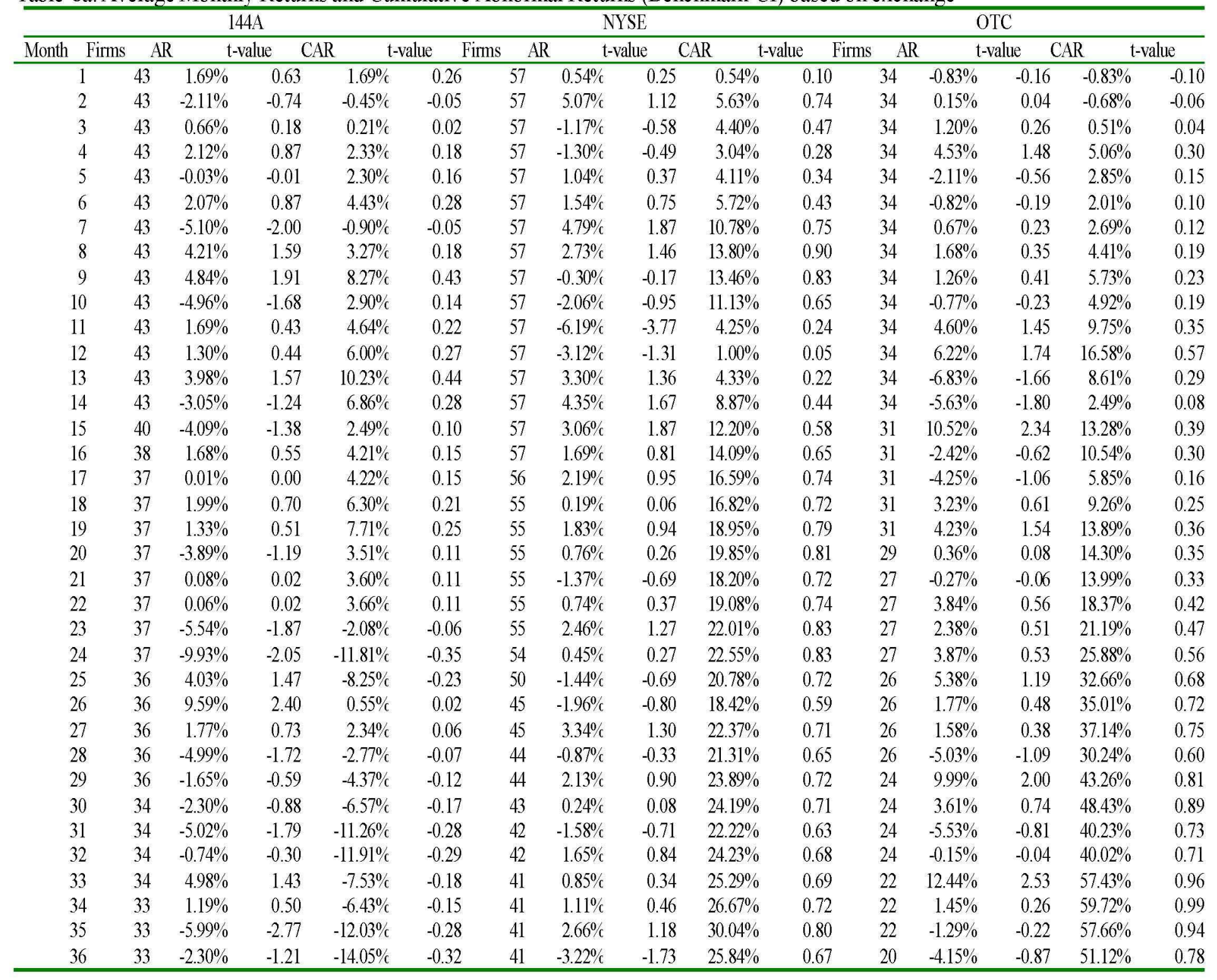


Table-8b: Average Monthly Returns and Cumulative Abnormal Returns (Benchmark-S\&P500) based on exchange

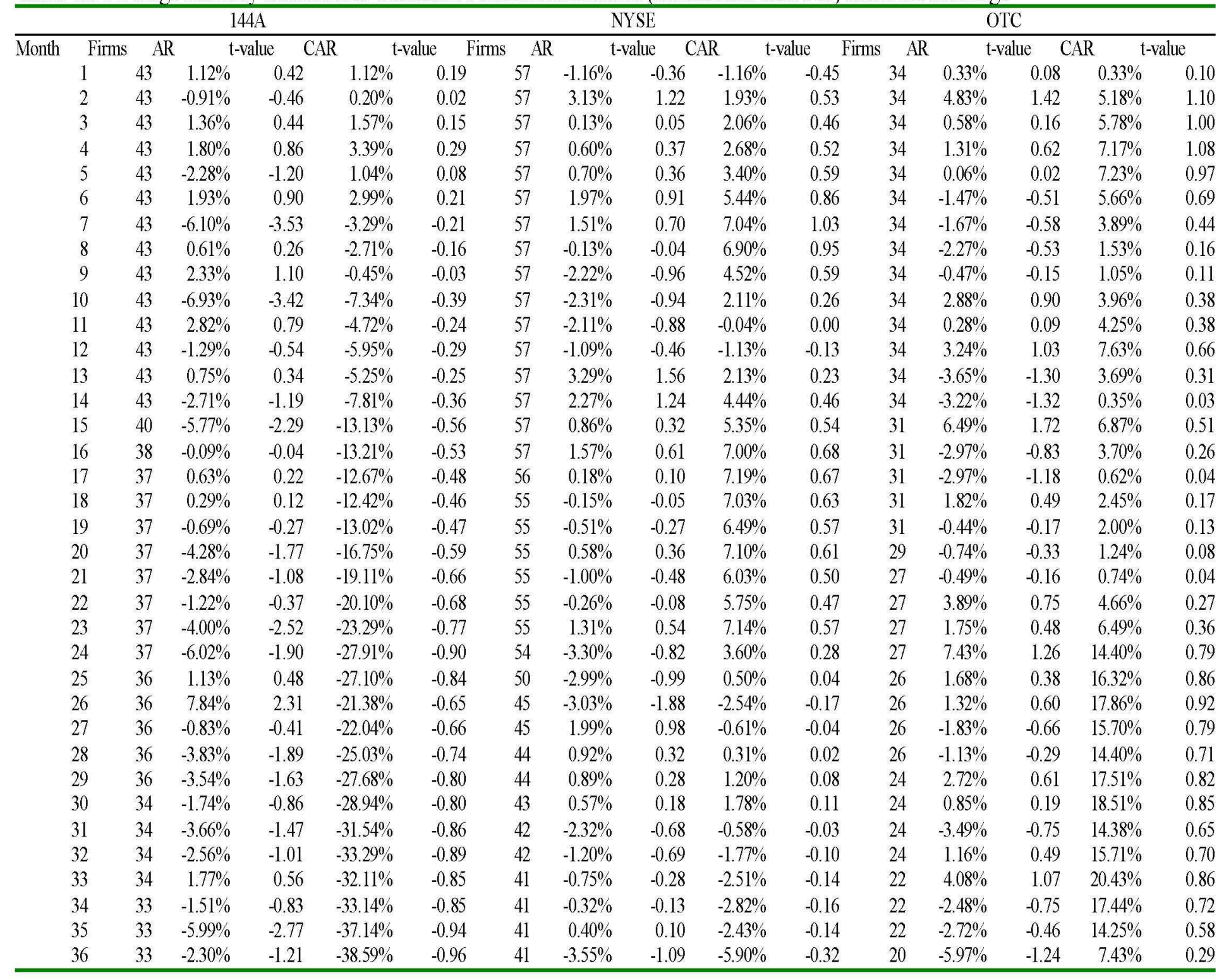


Table-8c: Average Monthly Returns and Cumulative Abnormal Returns (Benchmark-FTWorld) based on exchange classification

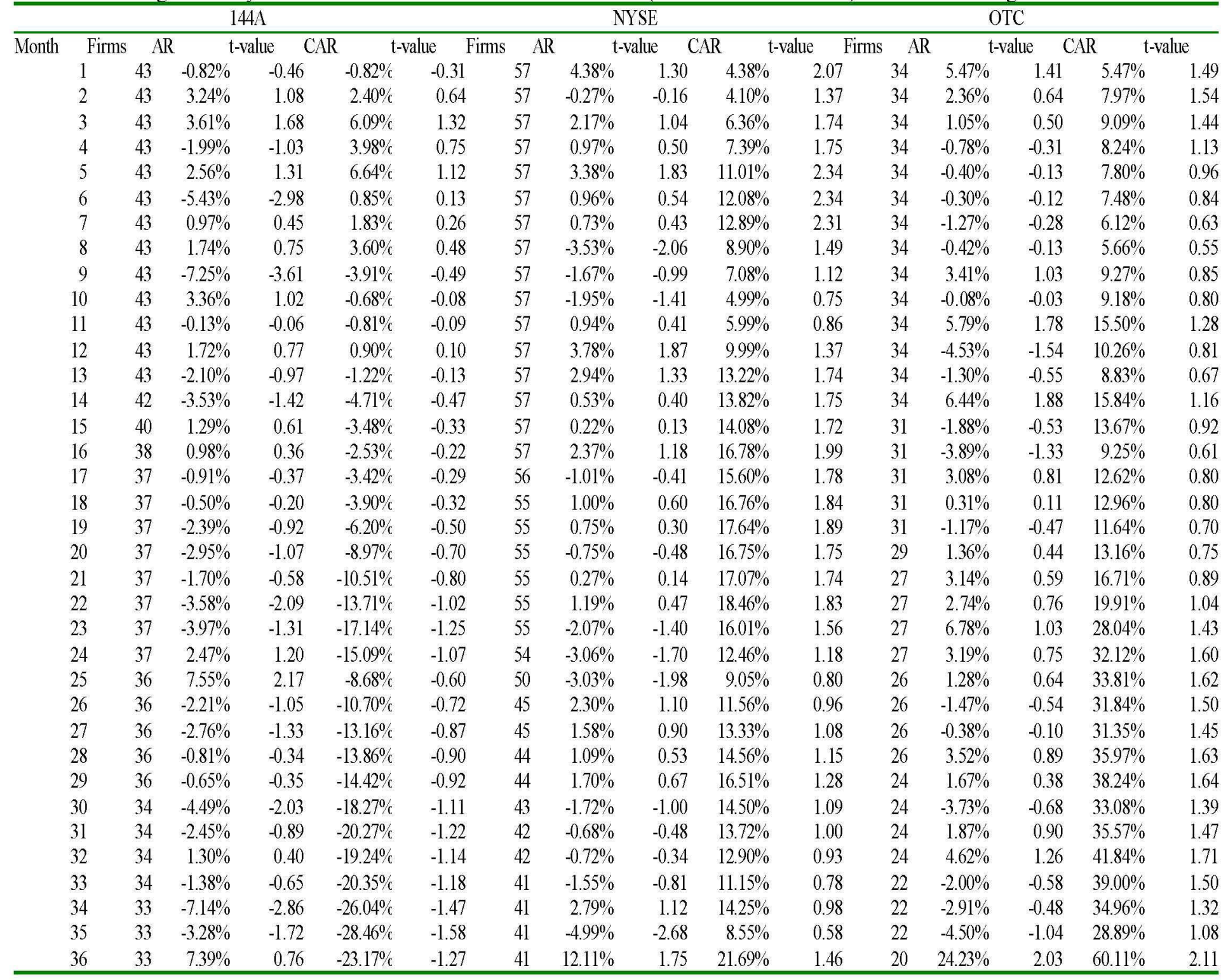




\section{Table-9: Holding Period Returns under the Buv and Hold Assumption}

Buy and hold returns were calculated from the closing price on the issue date to the anniversary of the holding period. The returns reflect capital gains only.

T statistics in the table were calculated to test the differences of mean (abnormal) holding period returns between emerging and developed market companies.

\begin{tabular}{|c|c|c|c|c|c|c|c|c|c|c|c|c|}
\hline \multicolumn{13}{|c|}{ Raw } \\
\hline & HPR-(12) & HPR-(24) & HPR-(36) & $\operatorname{AHPR}(12)$ & $\operatorname{AHP}(24)$ & $\operatorname{AHPR}(36)$ & $\operatorname{AHPR}(12)$ & $\operatorname{AHPR}(24)$ & $\operatorname{AHPR}(36)$ & AHPR-(12) & AHPR-(24) & AHPR-(36) \\
\hline Total & $21.35 \%$ & $30.83 \%$ & $20.35 \%$ & $13.33 \%$ & $16.91 \%$ & $11.16 \%$ & $9.68 \%$ & $0 \quad 3.87 \%$ & $-23.83 \%$ & $1.42 \%$ & $-14.37 \%$ & $-58.08 \%$ \\
\hline STDV & $76.79 \%$ & $113.40 \%$ & $95.09 \%$ & $64.49 \%$ & $98.72 \%$ & $75.88 \%$ & $76.07 \%$ & $118.04 \%$ & $98.14 \%$ & $77.92 \%$ & $115.26 \%$ & $102.37 \%$ \\
\hline MED & $5.95 \%$ & $-1.24 \%$ & $3.43 \%$ & $1.52 \%$ & $4.41 \%$ & $-4.93 \%$ & $-1.04 \%$ & $-24.23 \%$ & $-45.13 \%$ & $-10.41 \%$ & $-43.29 \%$ & $-89.47 \%$ \\
\hline Emerging & $15.04 \%$ & $22.25 \%$ & $2.36 \%$ & $8.04 \%$ & $14.58 \%$ & $8.07 \%$ & $3.15 \%$ & $-4.05 \%$ & $-42.19 \%$ & $-5.42 \%$ & $-20.95 \%$ & $-74.65 \%$ \\
\hline STDV & $72.97 \%$ & $122.98 \%$ & $94.95 \%$ & $58.97 \%$ & $107.30 \%$ & $76.45 \%$ & $72.23 \%$ & $129.16 \%$ & $98.41 \%$ & $73.35 \%$ & $125.89 \%$ & $103.10 \%$ \\
\hline MED & $1.10 \%$ & $-9.13 \%$ & $-25.26 \%$ & $1.46 \%$ & $-3.57 \%$ & $-8.29 \%$ & $-7.73 \%$ & $-36.21 \%$ & $-73.38 \%$ & $-19.01 \%$ & $-53.83 \%$ & $-104.84 \%$ \\
\hline $\mathrm{N}$ & 107 & 95 & 75 & 107 & 95 & 75 & 107 & 95 & 75 & 107 & 95 & 75 \\
\hline Developed & $40.61 \%$ & $58.96 \%$ & $66.24 \%$ & $29.50 \%$ & $24.54 \%$ & $19.04 \%$ & $22.31 \%$ & $29.80 \%$ & $23.00 \%$ & $29.66 \%$ & $7.19 \%$ & $-15.80 \%$ \\
\hline STDV & $86.73 \%$ & $72.36 \%$ & $80.00 \%$ & $78.57 \%$ & $59.72 \%$ & $75.13 \%$ & $89.36 \%$ & $69.39 \%$ & $81.67 \%$ & $85.80 \%$ & $69.49 \%$ & $88.81 \%$ \\
\hline MED & $10.44 \%$ & $40.66 \%$ & $52.70 \%$ & $4.22 \%$ & $19.01 \%$ & $21.54 \%$ & $-6.00 \%$ & $13.53 \%$ & $25.58 \%$ & $-0.63 \%$ & $-5.72 \%$ & $-13.61 \%$ \\
\hline $\mathrm{N}$ & 36 & 29 & 29 & 36 & 29 & 29 & 36 & 29 & 29 & 36 & 29 & 29 \\
\hline $\mathrm{T}$ & 1.59 & 1.99 & 3.46 & 1.50 & 0.64 & 0.66 & 1.16 & 1.83 & 3.44 & 2.20 & 1.54 & 2.89 \\
\hline
\end{tabular}

